\title{
AN EXCEPTIONAL LARGE SAMPLE OF THE EARLY MIOCENE CTENODACTYLINE RODENT SAYIMYS GIGANTEUS, SPECIFIC VARIATION AND TAXONOMIC IMPLICATIONS
}

\author{
JULIAN HARTMAN ${ }^{1,2}$, ANDREW A. VAN DE WEERD ${ }^{2,},{ }^{*}$,HANS DE BRUIJN ${ }^{2}$, WILMA WESSELS ${ }^{2}$ \\ 'Oranjepoldererf 36, 2807 NE Gouda, the Netherlands; e-mail: juulhartman@gmail.com. \\ ${ }^{2}$ Department of Earth Sciences, Utrecht University, Princetonlaan 8A, 3584 CB Utrecht, the Netherlands, P.O. Box 80021 3508TA Utrecht, \\ the Netherlands; e-mail: a.vandeweerd@uu.nl,hdbruijn@uu.nl,w.wessels@uu.nl. \\ ${ }^{*}$ corresponding author
}

Hartman, J., Weerd, A. A. van de, Bruijn, H. de, Wessels, W. (2019): An exceptional large sample of the early Miocene ctenodactyline rodent Sayimys giganteus, specific variation and taxonomic implications. - Fossil Imprint, 75(3-4): 359-382, Praha. ISSN 2533-4050 (print), ISSN 2533-4069 (on-line).

\begin{abstract}
An assemblage of the early Miocene Sayimys giganteus (Ctenodactylinae, Rodentia) from its type locality Keseköy, and smaller assemblages of Yapıntı and Horlak (Anatolia, Turkey) are described. Almost all Sayimys species are known from small collections of isolated cheek teeth. The very large assemblage from Keseköy is of special interest, because it allows the study of the intra-specific variation of dental morphology: size, the morphological changes through wear and the criteria for recognition of the tooth position of molars. The results have been used to review the formally named Sayimys species and to evaluate the dental features used to define the species. The review of the early and middle Miocene succession of Sayimys in the Siwaliks (Pakistan) resulted in the resurrection of $S$. minor; S. baskini is considered to be a junior synonym of $S$. minor. S. sivalensis and $S$. obliquidens are nomina dubia, and restricted to their holotypes, $S$. hintoni n. sp. is established for mediumsized Sayimys from the Kamlial, lower Chinji and Manchar Formations and S. chinjiensis is resurrected for Sayimys from the upper Chinji and Nagri Formations. It is suggested that the middle Miocene species Sayimys intermedius and $S$. assarrarensis from Saudi Arabia are synonymous.
\end{abstract}

Key words: Anatolia, Pakistan, Siwaliks, fossil rodents, Ctenodactylidae, revision Sayimys, synonymy, new species

Received: March 11, 2019 | Accepted: September 17, 2019 | Issued: December 30, 2019

\section{Introduction}

The first time one of the authors (H. de B.) heard about Gerhard Storch was in 1968 through Prof. G. H. R. von Koenigswald who, after deciding to exchange his position at the university of Utrecht for one with Senckenberg, told us about this charming, promising biologist who had just been appointed there. Those were the days of international focus on the palaeontology of small mammals. Sharing the passions for palaeontology and hunting, Gerhard and I became closer over the years. We miss his charm, knowledge and mild judgment, and we are happy to dedicate this study to him.

Jens Munthe (1980) noticed the large variability in Sayimys Wood, 1937, and wrote "New names for Miocene ctenodactylids should probably be proposed only if based on large samples or very distinctive morphological characters" (p. 22). Since 1980, seven new species of Sayimys have been described, six of them are these based on very small samples, while the distinctiveness of the features used is limited or debatable. The message of Munthe went unheeded, suggesting the need for a description of the large variability within Sayimys populations. In the following, we describe a large sample of $S$. giganteus LóPEZ-ANTOÑANZAS, Sen et SaraÇ, 2004 from Keseköy (Turkey), from the same level and locality as the type of the species. Our sample was collected in 1988 - 1989 by the team of Gerek Saraç, Engin Ünay (both Maden Tektik ve Arama, Ankara) and H. de B. (Utrecht University). The Sayimys specimens from two other sites in Turkey, Horlak and Yapint1, were collected by the same team. While the Sayimys specimens from Keseköy collected in 1988 - 1989 were under study, LópezAntoñanzas et al. (2004) defined Sayimys giganteus, based on a small sample from the same site. This small sample consists of 10 cheek teeth only, possibly representing two individuals. The collection described here consists of over 336 measurable specimens, representing a minimum number of 30 individuals, Yapınt 1 has delivered 65 specimens derived from a minimum of six individuals and Horlak yielded five specimens only. This material enlarges our knowledge of the 
genus, underscores the intra-specific variability and allows for a better understanding of small Sayimys assemblages.

In general, large collections of fossil and extant Ctenodactylinae species are relatively rare; most fossil species and genera are based on small numbers of specimens, in some cases on a single specimen. The large collection of Sayimys giganteus from Keseköy is thus an excellent, but rare, opportunity to study the variation within a single population, and to test the significance of the morphological and size differences within and between small assemblages.

\section{Localities}

A short description of the geological setting of the Keseköy locality (Text-fig. 1) is provided in Sümengen et al. (1990) and Krijgsman et al. (1996). Additional information is in Wessels et al. (2001), and a list of the rodent assemblage is given in Theocharopoulos (2000). The locality is correlated to the Mammal Neogene (MN) zone 3. The type of Sayimys giganteus López-Antoñanzas, Sen et SaraÇ, 2004 comes from the same locality as the material studied here. In the description of the species, it is mentioned that the type material is from two localities: Keseköy 1 and 2. However, all Keseköy material is from a thin (about $5 \mathrm{~cm}$ ) greenish clay bed intercalated in thick lacustrine diatomitic sediments. Normal faulting has dislocated the single thin fossiliferous bed, which is now at several locations in the hillside. A volcanic tuff below the fossiliferous bed has been dated as approximately $20.1 \pm 2.2 \mathrm{Ma}$ (Krijgsman et al. 1996). Illustrations of upper and lower dentitions of Sayimys sp. (now $S$. giganteus) from Keseköy were published by de Bruijn (1999).

The Yapıntı locality with a summary of the faunal assemblage has been described in Ünay et al. (2001). Based on the ages given in Ünay et al. (op. cit.), Yapıntı is slightly younger than the Keseköy locality. A lower and an upper premolar of Sayimys have been illustrated in Ünay et al.
(2001: fig. 4g, h); the material described here has been collected after 2001.

A description of the Horlak 2 locality is provided in Sümengen et al. (1990), along with a summary of the faunal assemblage. De Bruijn (1999) assigned the Horlak site to MN 4. Text-fig. 1 shows the location of the three sites in Turkey.

\section{Material and methods}

\section{Measurements, photographs, nomenclature}

A Leitz Ortholux microscope with a mechanical stage and measuring clocks was used for measuring dental elements. Measurements are given in millimetres. The measuring methods are shown in Text-fig. 2. Electron microscope photographs have been taken of a selection of the specimens. The specimens are depicted on the plates from the right side. If the original is from the left side, the specimen number has been underlined. The nomenclature used for parts of the cheek teeth is shown in Text-fig. 3, the terminology of the valleys (flexi and flexids) is after Baskin (1996), the anterolophulid is after de Bruijn et al. (1989). A sill is a slight elevation in the bottom of flexids or flexa near the tooth margin. Upper cheek teeth are indicated by upper case, lower cheek teeth by lower case.

\section{Abbreviations \\ KES Keseköy \\ YAP Yapintı \\ H.-GSP the Howard University-Geological Survey of Paki- stan localities}

\section{Recognizing tooth positions}

The distinction between isolated first and second molars in the Ctenodactylinae can be difficult, due to overlap in

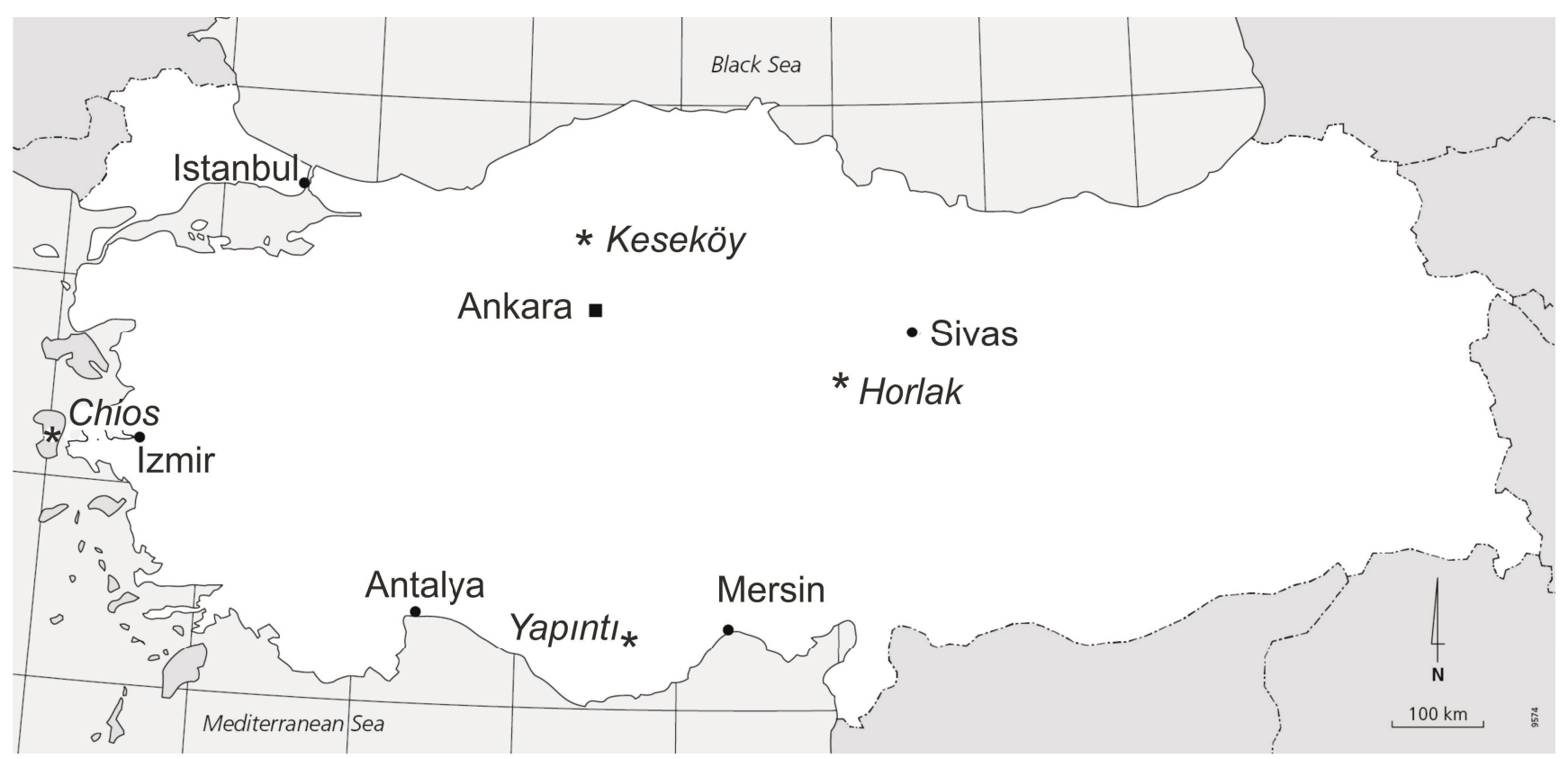

Text-fig. 1. Map of Turkey showing the localities Keseköy, Yapıntı and Horlak. 


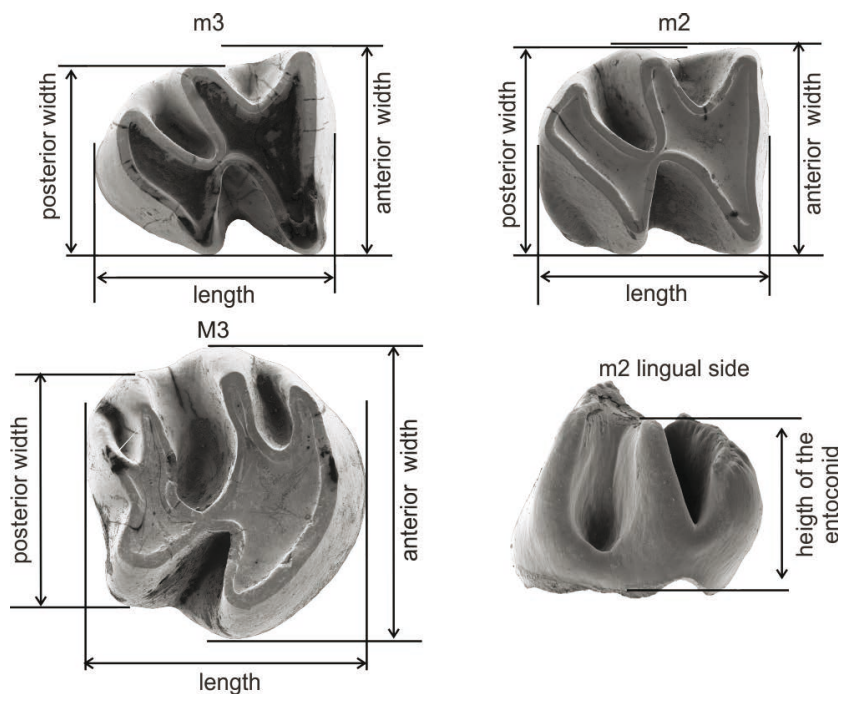

Text-fig. 2. Methods of taking measurements.

size and morphology. However, the large number of teeth available from Keseköy allowed a clear distinction. This distinction is based on size difference, the morphology of the posterior margin and the metaloph-posteroloph configuration. Text-fig. 4 shows that the $\mathrm{m} 1$ is smaller than the $\mathrm{m} 2$; the $\mathrm{m} 2$ and $\mathrm{m} 3$ have a similar size, but the $\mathrm{m} 3$ is on average larger. The $\mathrm{m} 1$ can be distinguished from the $\mathrm{m} 2$ by its anterior width; all $\mathrm{m} 1$ have an anterior width smaller than $2.20 \mathrm{~mm}$, while all second molars have an anterior width larger than $2.26 \mathrm{~mm}$. The distinction between the $\mathrm{m} 2$ and $\mathrm{m} 3$ is based on the shape of the posterior margin, strongly convex in $\mathrm{m} 3$, and absence of the interdental facet. In addition, most $\mathrm{m} 3$ lack a postero-labial cingulid. Textfig. 5 shows the size differences in upper molars; a bimodal distribution can be observed in the distribution of tooth lengths of the m1-2 and M1-2 (Text-fig. 6), and this is also observed in other larger samples of Sayimys. The M1 is not longer than $2.41 \mathrm{~mm}$, and the M2 not shorter than $2.43 \mathrm{~mm}$. The metaloph and posteroloph configuration of the M1 tend to form a $\mu$-shape, because the metaloph connects at right angles to the posteroloph. The metaloph-posteroloph tends to be $\mu$ - to $y$-shaped in M2, whereas in the M3 it is more $\mathrm{y}$-shaped. The posterior part of the M3 is less wide than its anterior side; this is reflected in the ratio anterior width/
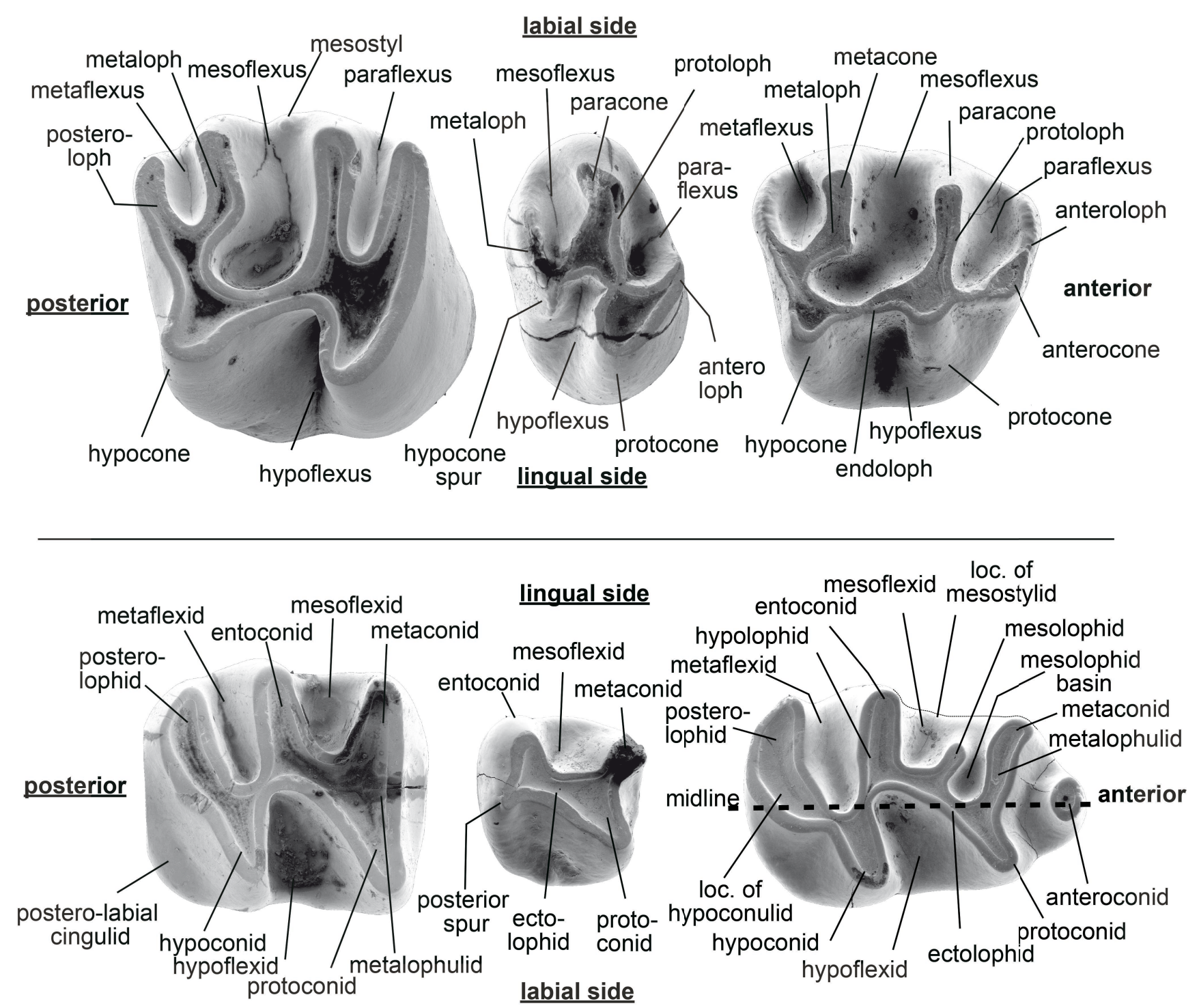

Text-fig. 3. Nomenclature of tooth parts. Upper row left to right: M1, P4, DP4; lower row left to right m1, p4, dp4. Loc. = location. The anterolophulid is not on this picture, it is the mid-line connection between anteroconid and the metalophulid. 


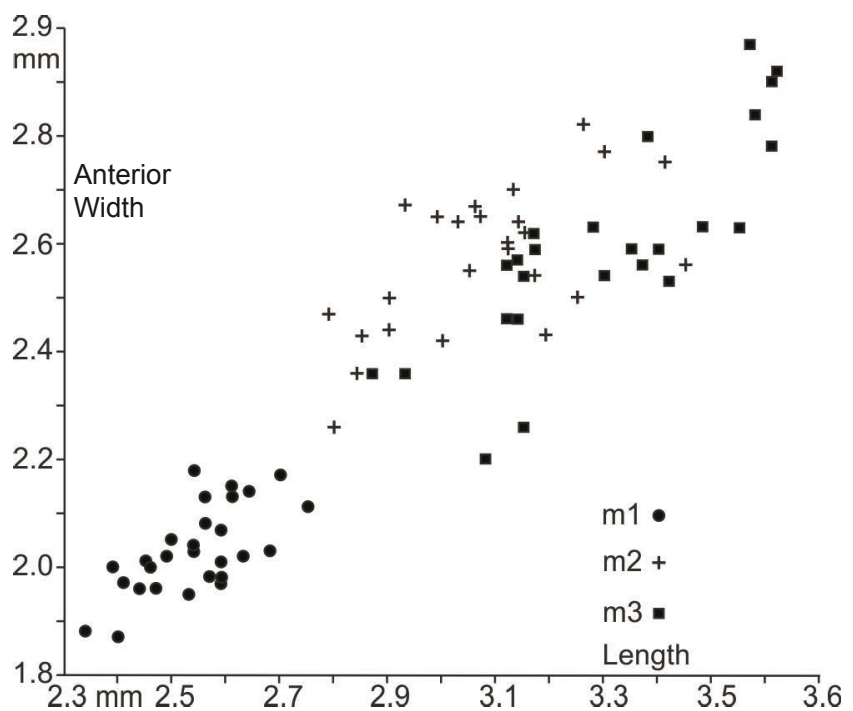

Text-fig. 4. Length-width scatter diagrams of lower molars of Sayimys giganteus from Keseköy.

posterior width: the ratio is relatively large in the M3 and small in the M2 (Text-fig. 7), it shows that there is a small area of overlap between the M2 and M3 near the ratio 1.15. In addition, the morphology of the posterior part of the M2 and M3 shows differences. In the M3 the posterior margin is concave, the metaloph-posteroloph aspect is y-shaped and the metaloph extends as a straight loph to about halfway the posteroloph.

\section{Crown height}

Teeth of Sayimys species are high-crowned and may show evolutionary trends toward higher crowns, as is suggested by Baskin (1996) for middle and late Miocene species in Pakistan. For that reason, the crown height has been measured in the manner shown in Text-fig. 2. The enamel-dentine border at the base of the crown thins gradually; its lower limit

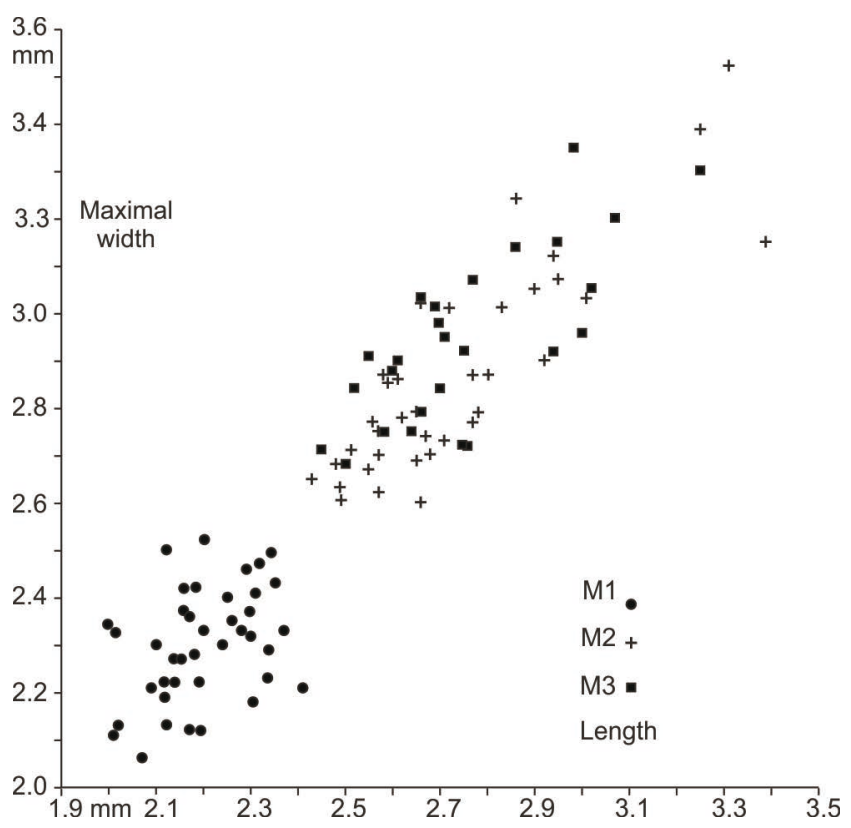

Text-fig. 5. Length-width scatter diagrams of upper molars of Sayimys giganteus from Keseköy. is fragile and variable and can be difficult to see. In addition, older individuals may show rather irregular occlusal surfaces. This results in large variation of measured crown heights of teeth showing the same degree of wear. In Text-fig. 8, five wear stages in cheek teeth, illustrated with line-drawings, have been defined; the corresponding measured maximum and minimum heights (h) for each wear stage are presented. For lower molars the height of the entoconid and for upper molars the height of the paracone has been measured.

\section{Systematic palaeontology}

\section{Family Ctenodactylidae Gervais, 1854 \\ Subamily Ctenodactylinae Hinton, 1933}

Genus Sayimys Wood, 1937

Ty pe s pecies. Sayimys perplexus Wood, 1937.

\section{Sayimys giganteus LóPEZ-ANTOÑANZAS, SEn et Saraç, 2004 \\ Text-figs 9-11}

Holotype. KSK1-100, a fragmentary left maxilla with P4-M1 (López-Antoñanzas et al. 2004: fig. 5C, D).

Ty p e locality. Keseköy 1 (Kizilcahamam, Ankara, Turkey).

Type horizon. Güvem Formation.

A g e. Early Miocene, MN 3 (López-Antoñanzas et al. 2004), $20.2 \pm 2.2 \mathrm{Ma}$ (Krijgsman et al. 1996, Wessels et al. 2001).

Materia 1. 335 cheek teeth, 261 isolated and 74 in partial jaws.

Measurements. Length-width measurements in Tab. 1, Text-figs 4 and 5, crown-height measurements in Text-fig. 8.

Original diagnosis. "Sayimys species of large size with the $\mathrm{m} 3$ lacking a constriction in the posterolophid; dp4 with a metalophulid II [= the mesolophid of Text-fig. 3] connecting with the metaconid or nearly reaching it. DP4 without metaflexus, but with a well-developed paraflexus; P4 with a long posteroloph connecting to the paracone and with the anteroloph joining the protocone; upper molars with a paraflexus longer than the metaflexus" (in LópezAntoñanzas et al. 2004).

Emended diagnosis. Large-sized species of Sayimys. On the dp4 the mesolophid can be: 1) absent, 2) present and half the length of the metalophulid or, 3) long and connected to a mesostylid. The rounded anteroconid is isolated; protoconid is extending less far labially than the hypoconid, mesolophid connecting at right angles to the ectolophid. The hypolophid connected to ectolophid at obtuse or about right angle.

Some p4 have a posterior spur at the junction of the hypolophid and the ectolophid, a stylid can be present on the postero-labial cingulid (lower arrow on Text-fig. 9, no 4058), as well as a vestigial mesolophid (upper arrow on Text-fig. 9 , no 4058). The metalophulid of lower molars is wide near 

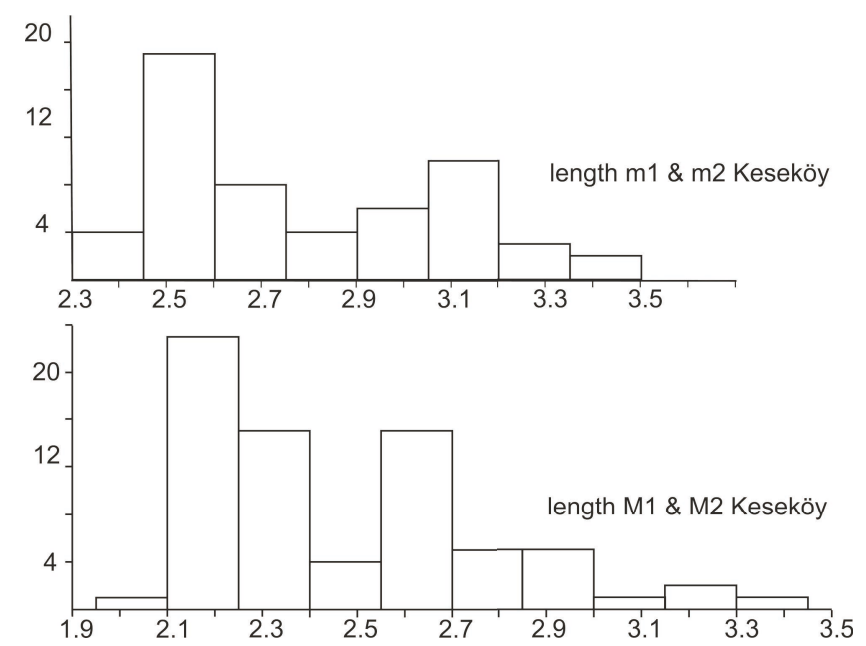

Text-fig. 6. Histograms of the length of Sayimys giganteus m1-m2 and M1-M2 from Keseköy showing bimodality.

the protoconid, the mesoflexid is short and v-shaped. The $\mathrm{m} 2$ and $\mathrm{m} 3$ are lacking a constriction in the posterolophid; a vestigial mesolophid is present in some lower molars (upper arrows on Text-fig. 9, no 4064 and 4084); $\mathrm{m} 1$ and $\mathrm{m} 2$ with a distinct postero-labial cingulid.

DP4 with paraflexus reaching the protocone, paraflexus longer than metaflexus; metaloph connecting at right angles to the posteroloph. P4 with metaloph of variable length and connected to the protoloph; a small hypocone or a hypocone spur is present, protocone is large.

Upper molars with a well-developed paraflexus and metaflexus, paraflexus longer than metaflexus reaching the protocone; M1 with a metaloph connecting at right angles to the posteroloph, M2 and M3 with a metaloph connecting not at right angles to the posteroloph.

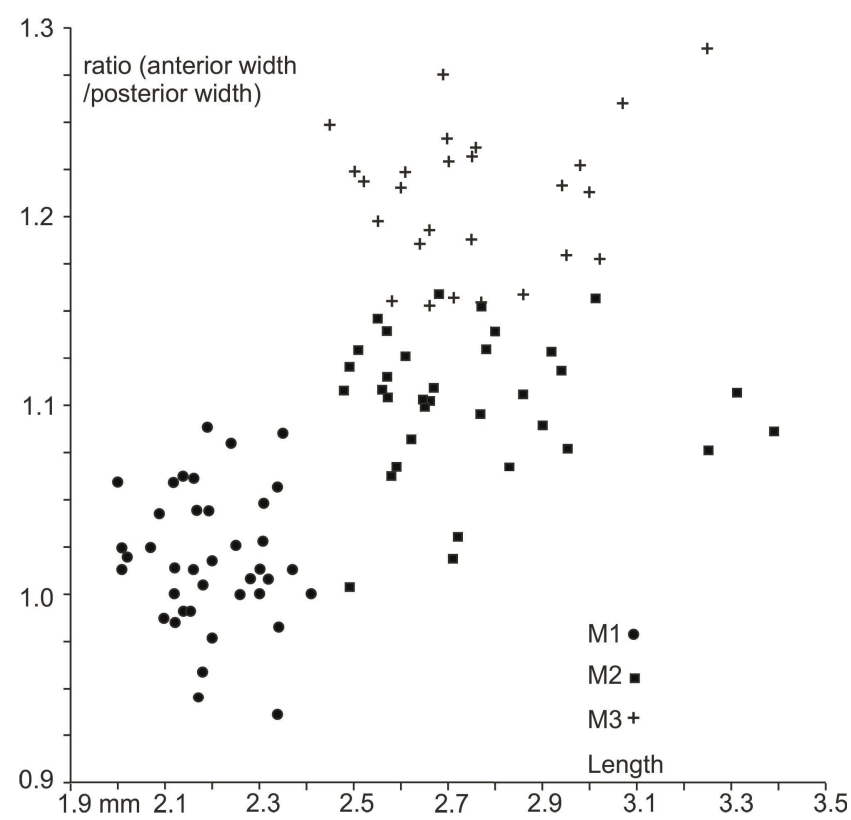

Text-fig. 7. Scatter diagram of molar length against the ratio anterior width / posterior width of upper molars of S. giganteus from Keseköy.

Description. dp4. The dp4 has a low crown, its anteroconid is isolated, circular to slightly ovoid and positioned on the mid-line of the tooth. The metaconid is located slightly anterior to the protoconid. The metalophulid of some slightly worn specimens appears to be vaguely S-shaped (4023 in Text-fig. 9) or can have a convex anterior side (4013 in Text-fig. 9). A mesolophid is present in 43 out of 48 specimens, but vestigial in 12 of these (4006 in Text-fig. 9). In the other 31 it is long, that is, extending halfway or more toward the lingual tooth margin. In six

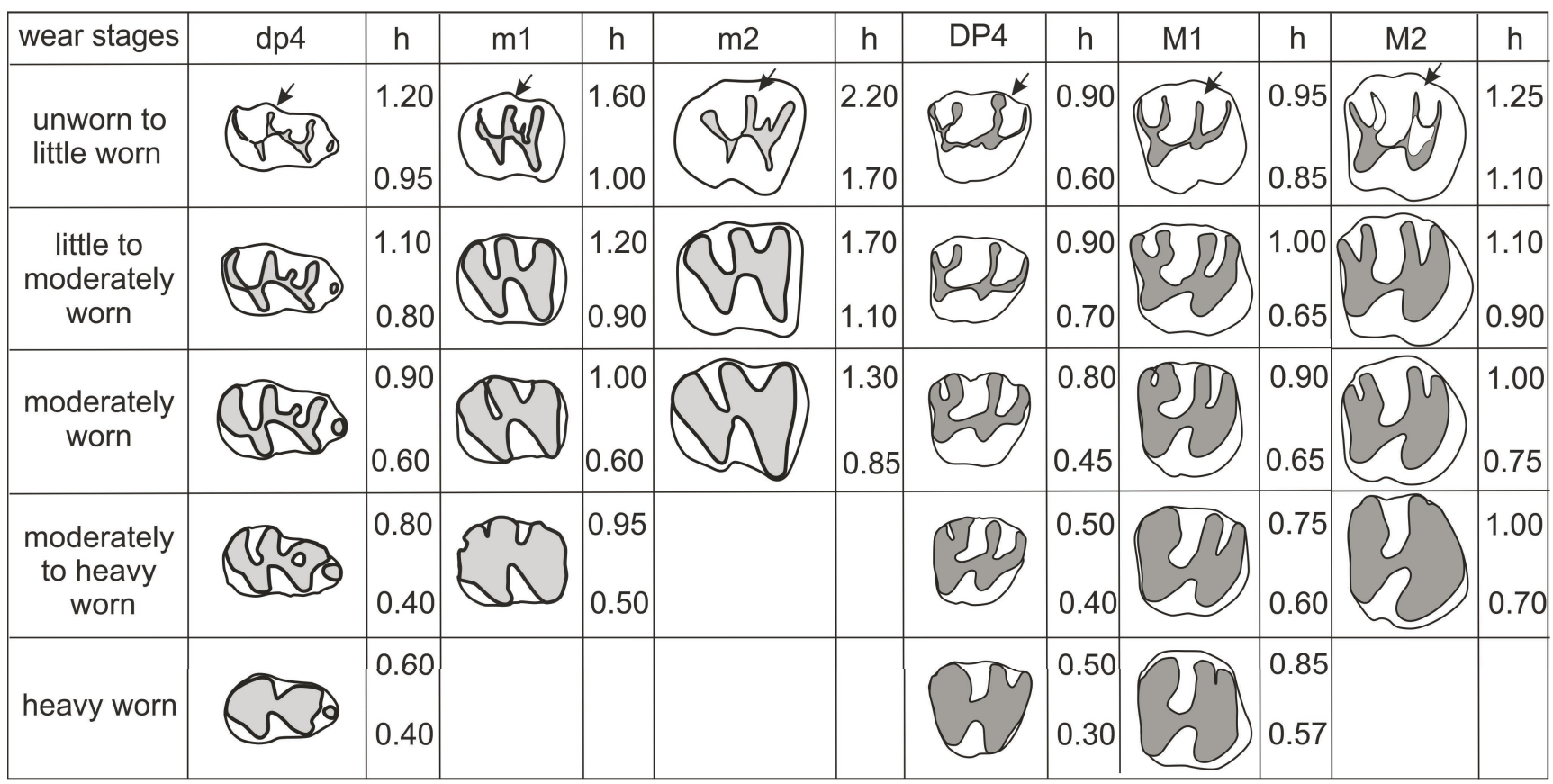

Text-fig. 8. Wear stages and height (h) of cheek teeth of Sayimys giganteus from Keseköy. Height in mm of the entoconid (arrow) in lower cheek teeth and paracone (arrow) in upper cheek teeth. Shown are the high value and a low value for each wear stage. Note that $h$ of the different wear stages may show large overlaps, in particular in those of worn teeth. This is due to the often-irregular occlusal surfaces of older individuals. 
Table 1. Measurements in mm of Sayimys giganteus from Keseköy.

\begin{tabular}{|c|c|c|c|c|c|c|c|c|c|c|c|c|}
\hline & \multicolumn{4}{|c|}{ Length } & \multicolumn{4}{|c|}{ Anterior width } & \multicolumn{4}{|c|}{ Posterior width } \\
\hline & range & average & SD & $\mathbf{N}$ & range & average & SD & $\mathbf{N}$ & range & average & SD & $\mathbf{N}$ \\
\hline DP3 & $0.69-0.87$ & 0.759 & 0.068 & 5 & - & - & - & - & $0.68-0.93$ & 0.754 & 0.092 & 7 \\
\hline DP4 & $1.78-2.32$ & 2.066 & 0.126 & 52 & $1.45-1.99$ & 1.823 & 0.109 & 53 & $1.40-2.06$ & 1.841 & 0.125 & 52 \\
\hline $\mathbf{P 4}$ & $1.09-1.46$ & 1.272 & 0.116 & 18 & - & - & - & - & $1.59-2.07$ & 1.884 & 0.143 & 18 \\
\hline M1 & $2.00-2.41$ & 2.201 & 0.109 & 40 & $2.06-2.50$ & 2.286 & 0.112 & 40 & $2.01-2.52$ & 2.248 & 0.134 & 40 \\
\hline M2 & $2.62-3.30$ & 2.736 & 0.231 & 36 & $2.61-3.52$ & 2.875 & 0.220 & 35 & $2.33-3.18$ & 2.624 & 0.221 & 36 \\
\hline M3 & $2.45-3.25$ & 2.748 & 0.200 & 27 & $2.38-3.35$ & 2.922 & 0.209 & 27 & $1.89-2.73$ & 2.414 & 0.186 & 27 \\
\hline dp4 & $2.49-3.08$ & 2.727 & 0.137 & 45 & $1.04-1.30$ & 1.180 & 0.072 & 47 & $1.43-1.78$ & 1.561 & 0.080 & 47 \\
\hline p4 & $1.29-1.77$ & 1.496 & 0.113 & 18 & - & - & - & - & $1.27-1.71$ & 1.484 & 0.140 & 18 \\
\hline m1 & $2.34-2.75$ & 2.543 & 0.098 & 32 & $1.65-2.15$ & 1.915 & 0.105 & 31 & $1.87-2.18$ & 2.031 & 0.077 & 31 \\
\hline m2 & $2.79-3.45$ & 3.076 & 0.179 & 25 & $2.26-2.82$ & 2.569 & 0.135 & 25 & $2.09-2.95$ & 2.486 & 0.184 & 25 \\
\hline m3 & $2.87-3.62$ & 3.302 & 0.218 & 25 & $2.20-2.97$ & 2.596 & 0.191 & 26 & $2.07-2.79$ & 2.439 & 0.159 & 29 \\
\hline
\end{tabular}

of the specimens, a small mesostylid is present; in three of these specimens a (vestigial) mesolophid is also present. In slightly worn specimens, the lingual end of the mesolophid is wide, suggesting a mesostylid. With increasing wear, the mesolophid eventually connects to the metalophulid to form an enamel lake (see the line drawings in Text-fig. 8). The mesolophid basin extends to the mid-line of the tooth or slightly beyond, but withdraws toward the lingual border with increasing wear. The mesoflexid has no sill at its entrance; it is deeper and wider than the metaflexid (Textfig. 11), whereas the mesolophid basin is shallower than the mesoflexid. The hypolophid connects at approximately a right angle to the ectolophid. In unworn condition, the connection of the hypolophid to the ectolophid is narrow, but it widens with increasing wear. The constriction at the connection of the hypolophid to the anterior arm of the hypoconid is more persistent. The hypoflexid is deep; it has no sill at the tooth margin. The posterolophid is curved. It is narrow at its connection with the hypoconid. An elevation in the posterolophid of unworn dp4 marks a hypoconulid. In some specimens, a low sill at the lingual border is present in the metaflexid, and an enamel lake appears with increasing wear. The metaflexid is deepest close to the hypoconid. The development of the postero-labial cingulid varies from weak to distinct.

p4. In little worn specimens, protoconid, metaconid and entoconid form a V-shape. The metalophid connects at right angles to the posterior side of the protoconid. In some premolars, the metalophid is constricted where it meets the protoconid. In five out of 18 specimens, a vestigial mesolophid is present (Text-fig. 9, 4058, arrowed). The ectolophid plus a short and a transversely oriented hypolophid connect to the entoconid; a posterior spur may be present. The postero-labial cingulum is distinct in most teeth; in eight a prominent cingulid-stylid is present (4058 on Text-fig. 9, lower arrow).

$\mathbf{m 1}$. The $\mathrm{m} 1$ has a high crown. The anterior margin of the occlusal surface is slightly concave, and becomes straighter and a bit convex with increasing wear. The metalophulid is broad at the protoconid-side and tapers lingually. In general, the metalophid extends less far lingually than the hypolophid.
In some slightly worn specimens a small short mesolophid is present (Text-fig. 9, 4064, arrowed), it is separated from the metalophulid by a narrow, very shallow valley, and fuses with the metalophulid at an early stage of wear. The mesoflexid does not reach the mid-line of the tooth; in occlusal view it is V-shaped when slightly worn, changing into U-shape with wear. The mesoflexid is shorter but deeper than the metaflexid (Text-fig. 11). The metaflexid may have a low sill at the tooth border. The connection between hypolophid and ectolophid becomes more confluent with wear, but the posterior margin of the hypolophid remains offset with respect to the ectolophid. The connection of the hypolophid to the anterior arm of the hypoconid is narrow. The hypoflexid is deeper than the mesoflexid and metaflexid. In two specimens, a low sill is present in the hypoflexid. In little-worn specimens, the posterolophid is slightly curved; in unworn specimens, a hypoconulid can be recognized as an elevation of the posterolophid. The metaflexid extends to the mid-line of the tooth, or slightly beyond it. In about half of the specimens, a prominent sill is present and connects to the posterolophid and hypolophid with wear, to form an enamel lake. The postero-labial cingulid is distinct in most specimens, weak in some specimens.

$\mathbf{m} 2$. The $\mathrm{m} 2$ and $\mathrm{m} 1$ are similar in morphology, but differ in length and width (Text-fig. 4), moreover, in unworn condition the crown of the $\mathrm{m} 2$ is higher (Text-fig. 11). Also, there are some minor morphological differences. On $\mathrm{m} 2$, the connection between ectolophid and hypolophid is wider, and these lophids are oriented more in line than on m1. As on $\mathrm{m} 1$, a short mesolophid branch may be present in unworn specimens, but it fuses with the metalophulid in an early stage of wear. The mesoflexid is similar to that in the $\mathrm{m} 1$, but a weak sill is present in more specimens. In $\mathrm{m} 2$, the hypoflexid is more in line with the metaflexid compared to the $\mathrm{m} 1$. The connection between hypolophid and anterior arm of the hypoconid is narrow. The posterolophid is less curved than in the $\mathrm{m} 1$ in early stages of wear, and when moderately worn, it is straight and obliquely oriented. The posterolophidhypoconid connection is wide. The sill at the lingual tooth border in the metaflexid is similar to $\mathrm{m} 1$; with increasing wear, the metaflexid becomes narrower at its lingual margin. 
m3

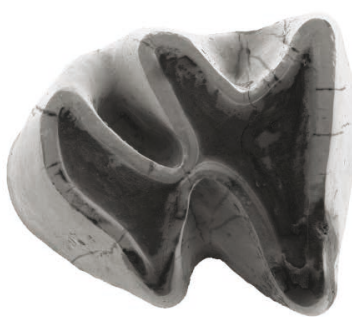

KES4083

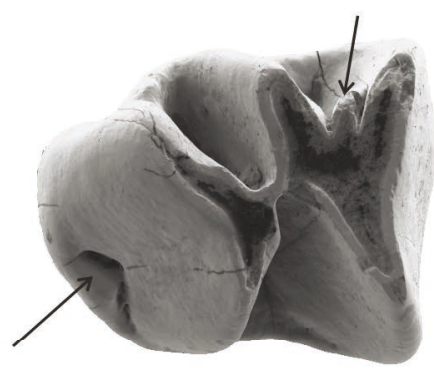

KES4084

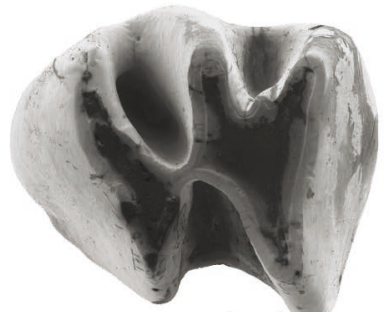

KES4124

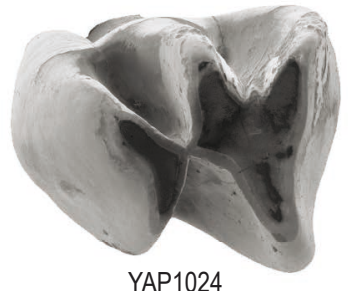

YAP1024 m2

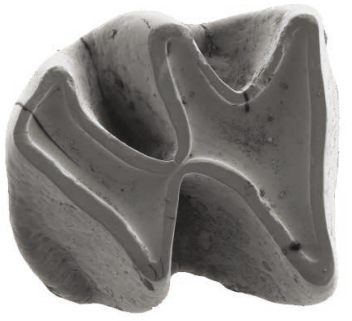

KES4078

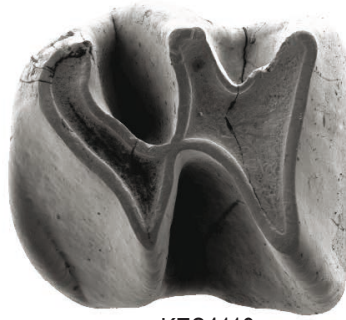

KES4119

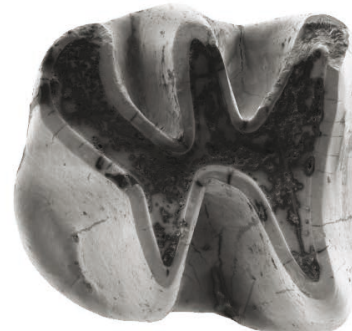

$\underline{\text { KES4122 }}$

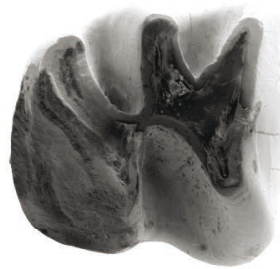

YAP1012 m1

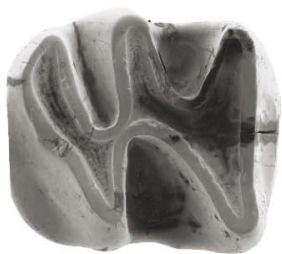

KES4070

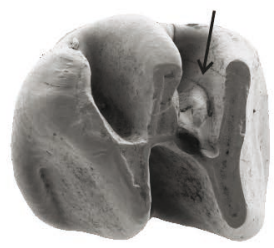

KES4064

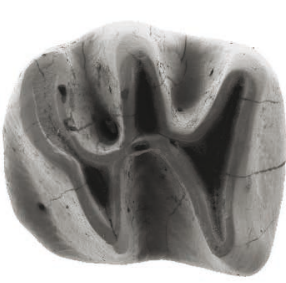

KES4111

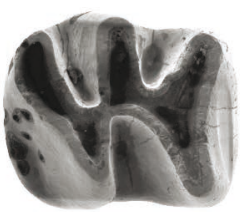

YAP1020 p4

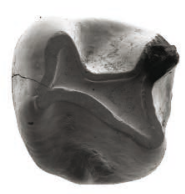

KES4053

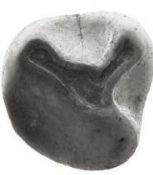

KES4048
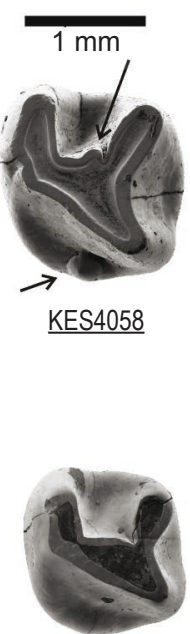

YAP1005

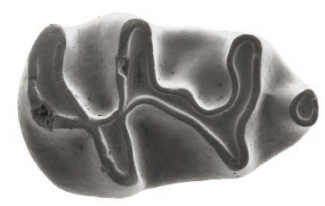

KES4006

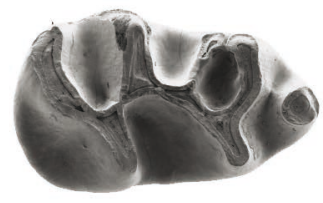

KES4013

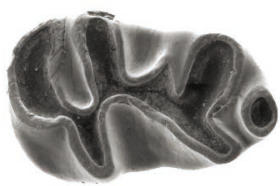

YAP1000

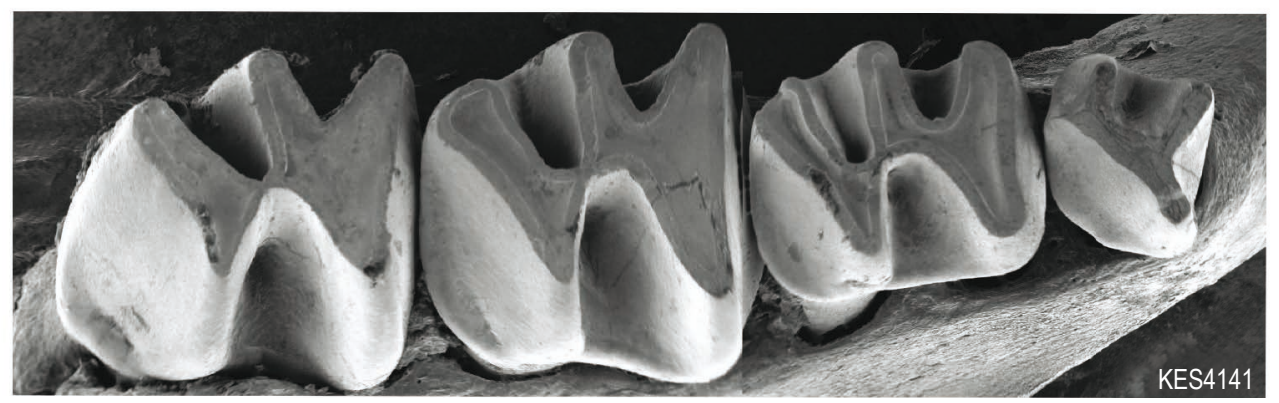

Text-fig. 9. Lower molars and premolars of Sayimys giganteus from Keseköy and Yapıntı (= YAP numbers) shown as right specimens. Left side specimens are shown in mirror image, these have underlined specimen numbers.

m3. The $\mathrm{m} 3$ is somewhat larger (Text-fig. 4) and higher than $\mathrm{m} 2$. It can be distinguished by its narrow convex posterior margin; its posterior width is smaller than its anterior width. The metaconid lies anterior to the labial part of the protoconid. The apex of the unworn protoconid lies slightly more toward the mid-line of the molar relative to that of the hypoconid. The protoconid is oblique and the hypoconid is transverse. In little-worn $\mathrm{m} 3$, a short mesolophid is present, but it merges with the metalophulid at an early wear stage. The mesoflexid has a V-shape, which does not reach the mid-line of the tooth. In lingual view, the mesoflexid is deeper than the metaflexid (Text-fig. 11); a minor sill may be present. The metaflexid is long and has a prominent sill. The straight hypolophid is confluent, in line with the ectolophid. The connection of the hypoconid to the ectolophid is narrow. The hypoflexid is deeper than 

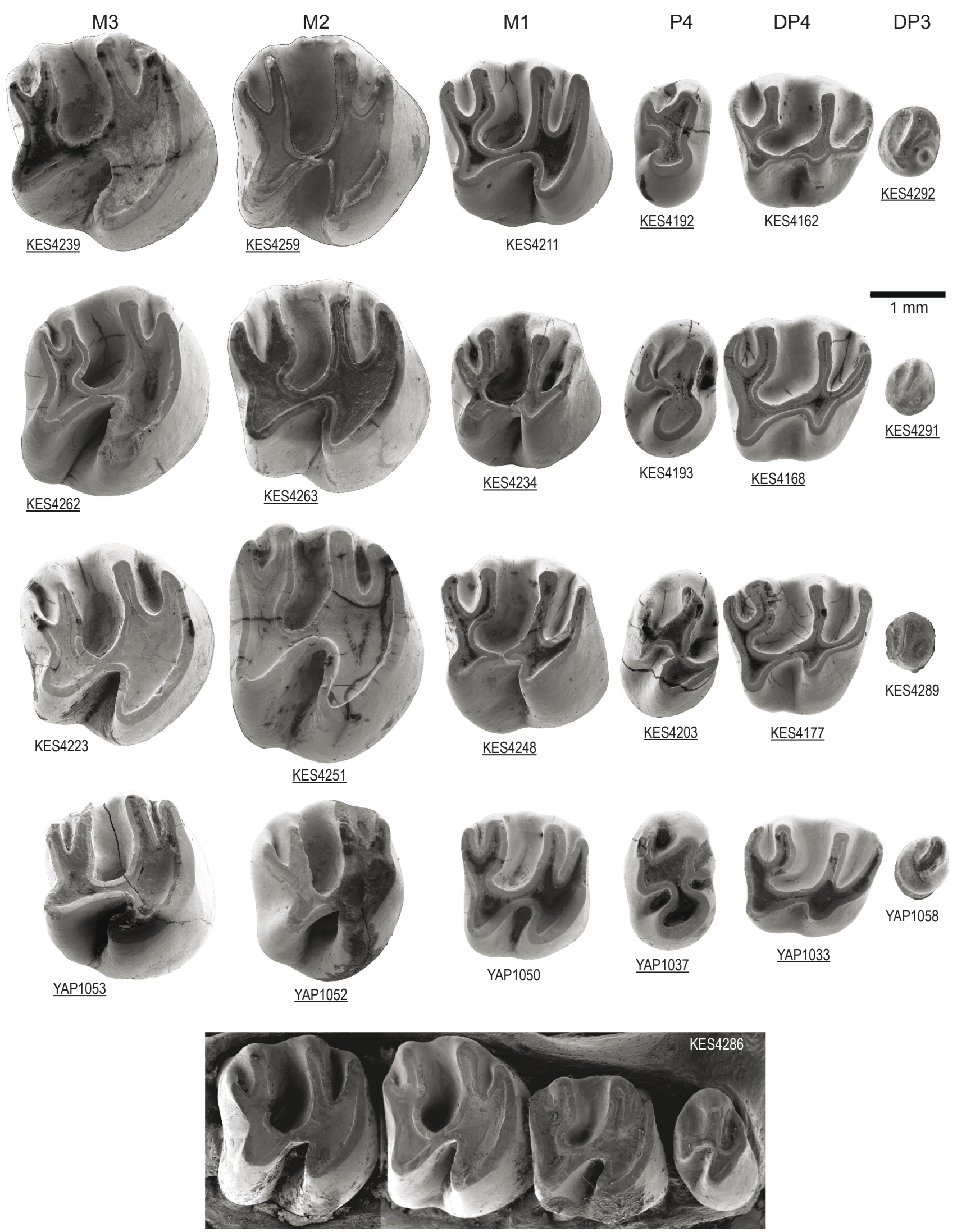

Text-fig. 10. Upper cheek teeth of Sayimys giganteus from Keseköy and Yapıntı (= YAP numbers) shown as right specimens. Left side specimens are shown in mirror image, these have underlined specimen numbers.

the meso- and metaflexid. The posterolophid is more or less straight and directed obliquely. The postero-labial cingulid can be absent, weak or distinct, with a stylid positioned on it in some specimens (Text-fig. 9, 4084, arrowed).
DP3. This small low-crowned element has a variable morphology. A complex specimen is in Text-fig. 10 (no 4292); it shows an obliquely oriented loph, which is wider and highest at its labial end. An anterocone is present. 

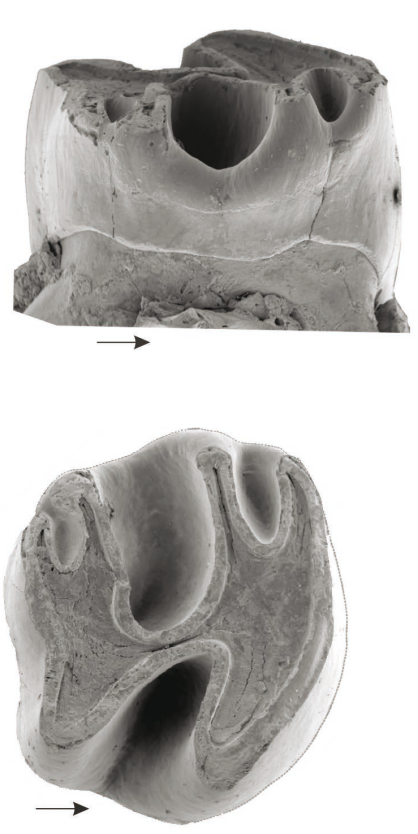

M3: 4229
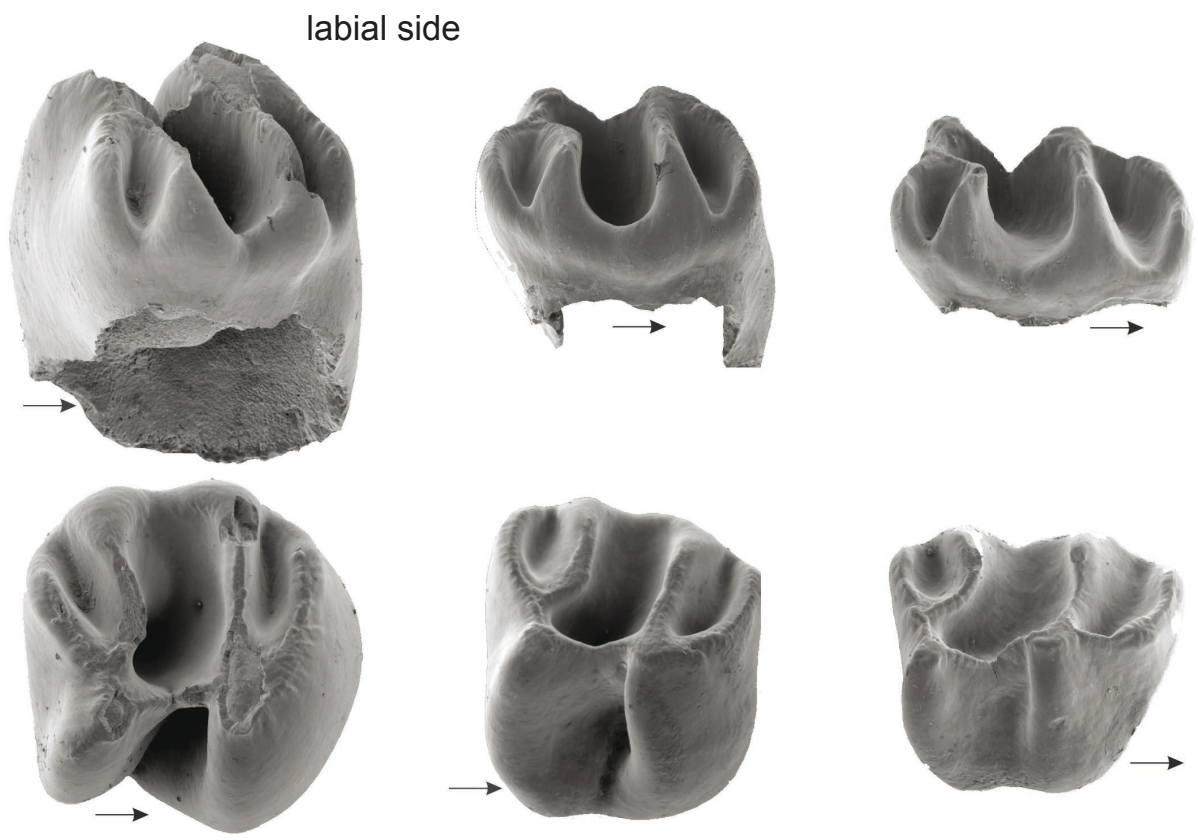

M2: 4208

M1: 4219

DP4: 4170

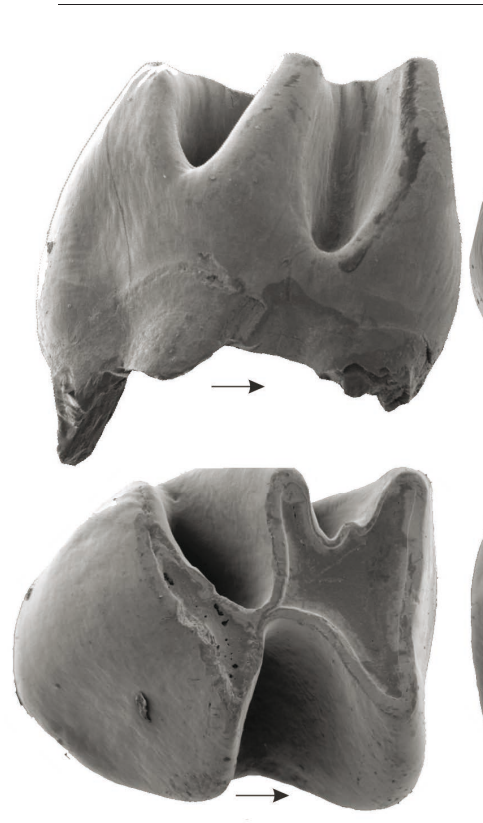

m3: 4124

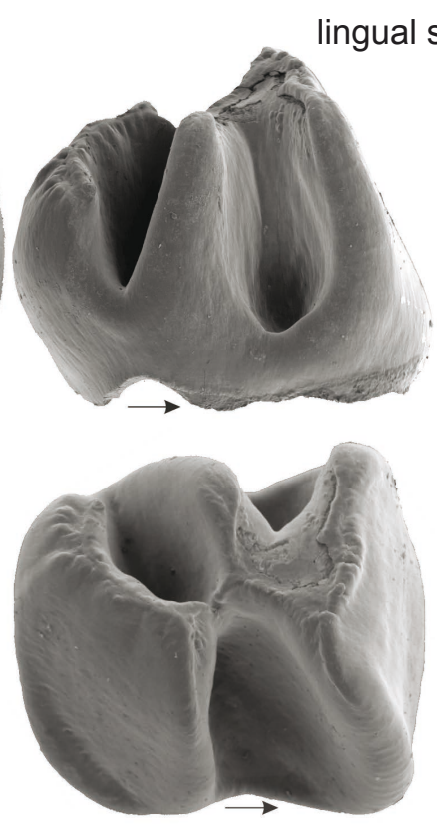

m2: 4118
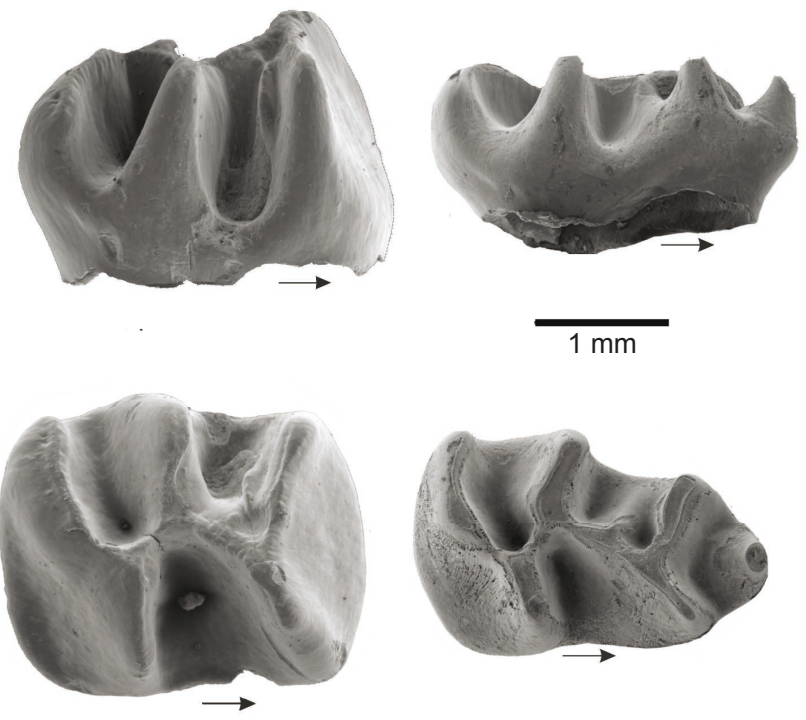

m1: 4112
$1 \mathrm{~mm}$

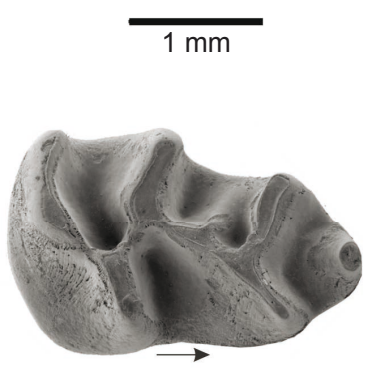

dp4: 4004

Text-fig. 11. Cheek teeth of Sayimys giganteus from Keseköy. Anterior sides are indicated by arrows. Top row: labial sides of M3, M2, M1 and DP4, images horizontally-mirrored. Second row: occlusal surfaces of M3, M2, M1 and DP4 of the same specimens. Third row: lingual sides of $\mathrm{m} 3, \mathrm{~m} 2, \mathrm{~m} 1$ and dp4, images horizontally-mirrored. Lower row: occlusal surfaces of $\mathrm{m} 3, \mathrm{~m} 2, \mathrm{~m} 1$ and dp4 of the same specimens.

Posteriorly, a low cingulum is separated from the oblique loph by a valley. Other specimens show a single sharp cusp with traces of a subsidiary cusp and cingulum.

DP4. The DP4 has a low crown, with morphology showing minor variation (Text-fig. 10). Some DP4 have a thickening in the anteroloph at the anterocone position, in others, this is absent. The labial end of the anteroloph shows a thickening in some specimens, in others it tapers. In some unworn specimens, the paracone seems isolated, due to a low protoloph. Unworn specimens show that the apex of the protocone is located more labially than the hypocone; protocone and hypocone are higher than paracone and metacone. With increasing wear, the labial end of the posteroloph connects to the metacone, due to the presence of a sill in the metaflexus. In late stages of wear, the metaloph merges with the posteroloph, and the protoloph with the anteroloph. In such specimens, the anterior fused loph is wider than the posterior fused loph.

P4. We are not certain about the homology of the elements of the P4; we follow here Text-fig. 3, where a 
relatively unreduced specimen is shown. Text-fig. 10 shows the morphological variety from strongly reduced (no 4192) to relatively weakly reduced (no 4203). The strongly-reduced specimens show two cusps, the protocone and the paracone, connected by a transversely oriented loph and a small posterior spur. Its hypoflexus is at the posterior side, while the paraflexus is absent. In the weakly-reduced specimen, the mesoflexus and paraflexus are both present, the hypoflexus is located lingually. Protoloph and posteroloph (= metaloph) are both well-developed.

M1. The M1 is high-crowned. Its protoloph is straight or slightly curved; the posterior rim is convex and confluent with the labial margin of the endoloph. The apex of the protocone of unworn specimens is located more internally than that of the hypocone; protocone and hypocone are higher than metacone and paracone. The posteroloph is straight and obliquely oriented; its tip at the labial end is often slightly curved. The metaloph is connected about halfway to the posteroloph. The straight paraflexus extends to the protocone, decreasing in length with wear. In labial view (Text-fig. 11), the paraflexus is as low and wide as the metaflexus. In heavily worn specimens, protoloph and anteroloph are fused (Text-fig. 8). The mesoflexus extends beyond the mid-line of the tooth, is deepest internally, and a low sill is present near the tooth margin. The sill in the short metaflexus is not prominent; an enamel lake does not form in all worn specimens. The metaloph and posteroloph are completely fused in worn specimens (Text-fig. 8). The fused anterior loph is wider than the fused posterior loph.

M2. The M2 is distinctly wider and longer, and in unworn condition, higher than the M1 (Text-figs 5, 6, 11), and it is widest anteriorly. The lophs and cusps are confluently fused into ridges that are arc-shaped. Anteroloph and protocone form the smoothly bow-shaped anterior side of the molar. The protoloph is transverse or slightly oblique. The posterior side of the protoloph curves smoothly and confluently into the labial margin of the endoloph. There is some variation in the configuration of the posteroloph and metaloph, related to stages of wear. The posteroloph seems an offshoot from the curved loph formed by metacone, metaloph and hypocone. In other specimens, the posteroloph seems to split smoothly from the metaloph. Unlike in M1, the metaloph and posteroloph do not meet at a right angle. The paraflexus extends to the protocone in lightly worn specimens, but decreases in length with wear (Text-fig. 8). Usually a low sill is present, and the paraflexus can form an enamel lake in later wear stages. The paraflexus and metaflexus are about equally deep and wide (Text-fig. 11); both are shallower than the mesoflexus and hypoflexus. The mesoflexus extends beyond the mid-line. A sill is present in the mesoflexus; the deepest part of the mesoflexus lies internally. The hypoflexus is deeper than the mesoflexus, but it is shorter, not reaching the mid-line of the tooth. A sill is present in the metaflexus of most specimens; in advanced stages of wear, the metaflexus forms an enamel lake, in later stages of wear the metaloph and posteroloph are completely fused.

M3. The isolated M3 is similar in length and width to the M2 (Text-fig. 5), but higher in an unworn condition. The posterior side of the M3 is relatively narrow, resulting in an anterior/posterior width ratio that is larger in the M3 than in the M2 (Text-fig. 7). The M3 has a smooth convex anterior margin, and a concave posterior margin. Similar to the M2, the ridges formed by the confluently fused lophs and cusps are more or less arc-shaped, but in the M3 arcs are stronger bowed, the labial tips more posteriorly located. The metaloph meets halfway to the posteroloph, the posteroloph seems a posterior offshoot from the curved ridge formed by the metacone, metaloph and hypocone. In some specimens and stages of wear, the metaloph seems an anterior offshoot of a confluent arc formed by posteroloph and hypocone. The morphology of the occlusal surface and depth of flexi are like those in the M2.

Variation in size. Most samples of Sayimys are small. The two large samples of Sayimys previously known are Daud Khel and H.-GSP82.24 in Pakistan (Munthe 1980, de Bruijn et al. 1989). Together with the Keseköy assemblage, these allow a reliable estimate of the variation in length and width. Length-width variation (size) of rodent teeth is discussed in Freudenthal and Cuenca Bescos (1984). These authors introduced a simple coefficient of variation,

Table 2. Coefficient of variation V' in three large samples of Sayimys, Keseköy, Daud Khel and H.-GSP82.24. N = number of specimens.

\begin{tabular}{|c|c|c|c|c|c|c|c|c|c|c|c|c|c|}
\hline & \multicolumn{6}{|c|}{ Upper premolars and molars } & & \multicolumn{6}{|c|}{ Lower premolars and molars } \\
\hline & \multicolumn{2}{|c|}{ Keseköy } & \multicolumn{2}{|c|}{ Daud Khel } & \multicolumn{2}{|c|}{ H.-GSP82.24 } & & \multicolumn{2}{|c|}{ Keseköy } & \multicolumn{2}{|c|}{ Daud Khel } & \multicolumn{2}{|c|}{ H.-GSP82.24 } \\
\hline & V' & $\mathbf{N}$ & V' & $\mathbf{N}$ & V' & $\mathbf{N}$ & & V' & $\mathbf{N}$ & V' & $\mathbf{N}$ & V' & $\mathbf{N}$ \\
\hline DP4 length & 29 & 50 & 8 & 14 & 22 & 26 & dp4 length & 21 & 46 & 12 & 12 & 21 & 24 \\
\hline DP4 width & 26 & 53 & 25 & 14 & 33 & 26 & dp4 width & 22 & 48 & 14 & 12 & 38 & 24 \\
\hline P4 length & 31 & 18 & 22 & 14 & 30 & 5 & p4 length & 31 & 18 & 13 & 25 & 24 & 12 \\
\hline P4 width & 30 & 18 & 28 & 14 & 25 & 5 & p4 width & 30 & 18 & 18 & 25 & 34 & 12 \\
\hline M1 length & 19 & 40 & 20 & 29 & 13 & 21 & m1 length & 16 & 32 & 26 & 33 & 13 & 21 \\
\hline M1 width & 19 & 40 & 34 & 29 & 25 & 21 & m1 width & 15 & 32 & 29 & 33 & 24 & 21 \\
\hline M2 length & 33 & 37 & 28 & 31 & 17 & 16 & m2 length & 21 & 24 & 19 & 28 & 24 & 18 \\
\hline M2 width & 35 & 36 & 28 & 31 & 22 & 16 & m2 width & 22 & 24 & 16 & 28 & 19 & 16 \\
\hline M1-2 length & 52 & 77 & 34 & 60 & 33 & 37 & M1-2 length & 38 & 56 & 33 & 61 & 28 & 38 \\
\hline M1-2 width & 52 & 76 & 50 & 60 & 44 & 37 & M1-2 width & 41 & 56 & 51 & 61 & 47 & 36 \\
\hline M3 length & 31 & 26 & 30 & 21 & 21 & 10 & m3 length & 25 & 27 & 16 & 18 & 25 & 18 \\
\hline M3 width & 33 & 26 & 18 & 21 & 22 & 10 & m3 width & 30 & 27 & 20 & 18 & 21 & 17 \\
\hline
\end{tabular}


Table 3. An estimate for the range of the length (in $\mathrm{mm}$ ) of the dp4 and $\mathbf{m 1 - 2}$ in small samples $(n=1$ to $n=5)$. The range has been estimated using values for the coefficient of variation $V$ ' calculated from large assemblages of related species. See text for further explanation.

\begin{tabular}{lccccc}
\hline & midpoint & V' & range & min & max \\
\hline dp4 As Sarrar & $1.73(\mathrm{n}=2)$ & 20 & 0.35 & 1.56 & 1.90 \\
dp4 Al Jadidah & $1.90(\mathrm{n}=1)$ & 20 & 0.38 & 1.71 & 2.09 \\
dp4 Chios & $2.30(\mathrm{n}=2)$ & 20 & 0.46 & 2.07 & 2.53 \\
& & & & & \\
m1-2 As Sarrar & $2.46(\mathrm{n}=3)$ & 40 & 0.98 & 1.97 & 2.95 \\
m1-2 Al Jadidah & $2.44(\mathrm{n}=2)$ & 40 & 0.98 & 1.95 & 2.93 \\
m1-2 Chios & $2.24(\mathrm{n}=5)$ & 40 & 0.90 & 1.79 & 2.69 \\
\hline
\end{tabular}

$\mathrm{V}^{\prime}=100 \mathrm{r} / \mathrm{m}$ in which $\mathrm{r}$ is the range (the difference between the maximum and minimum) and $\mathrm{m}$ is the midpoint between maximum and minimum. Tab. 2 shows values for $\mathrm{V}$ ' for the three large samples of Sayimys; note that the value of $\mathrm{V}^{\prime}$ for undivided assemblages of first and second molars is large.
The values for V' calculated from the three large Sayimys populations may be used to estimate a size range if only a small sample is available. To show this, we have estimated a size range for the dp4 and $\mathrm{m} 1-2$ of three small samples: Sayimys intermedius from its type locality Al Jadidah, $S$. assarrarensis from As Sarrar and Sayimys aff. intermedius from Chios (data in López-Antoñanzas and Sen 2004, LópezAntoñanzas et al. 2005). Tab. 3 shows that the estimated ranges for the m1-2 and dp4 of Al Jadidah and As Sarrar are largely overlapping. The Chios $\mathrm{m} 1-2$ is similar in size to that from Al Jadidah and As Sarrar, but its dp4 is much larger and outside the range of the other two sites.

The calculated ranges are indicative; in this exercise the available measurements are assumed to be close to the midpoint of the constructed range, a presumption not necessarily true.

Text-figs 12 and 13 show the ranges and averages of the length of $\mathrm{dp} 4$ and $\mathrm{m} 3$ of most species of Sayimys compiled from the literature; length ranges of DP4 and M3 show a similar picture, but are not shown here. Diagrams of first and second molars are not helpful, because these molars are

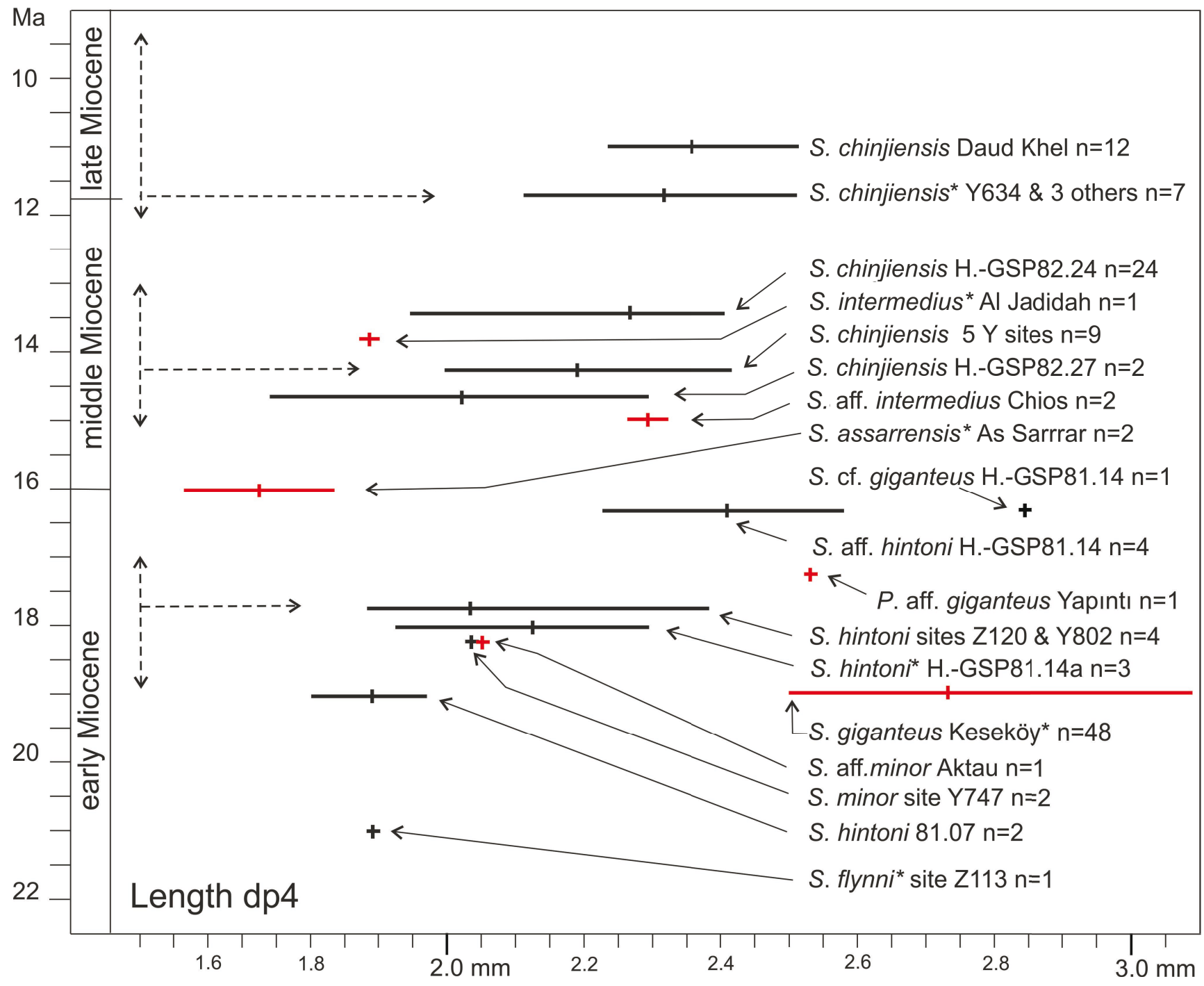

Text-fig. 12. Ranges of the length of the dp4 based on data from the literature. Vertical scale in Ma, the samples are from the Siwaliks (black) and Turkey, Greece and Arabia (red). Type localities of species are indicated with an asterisk. The $\mathrm{Y}$ and $\mathrm{Z}$ sites are from Baskin (1996), its size ranges are composed of data from several localities and the vertical arrowed broken line indicates the age range of these sites. 


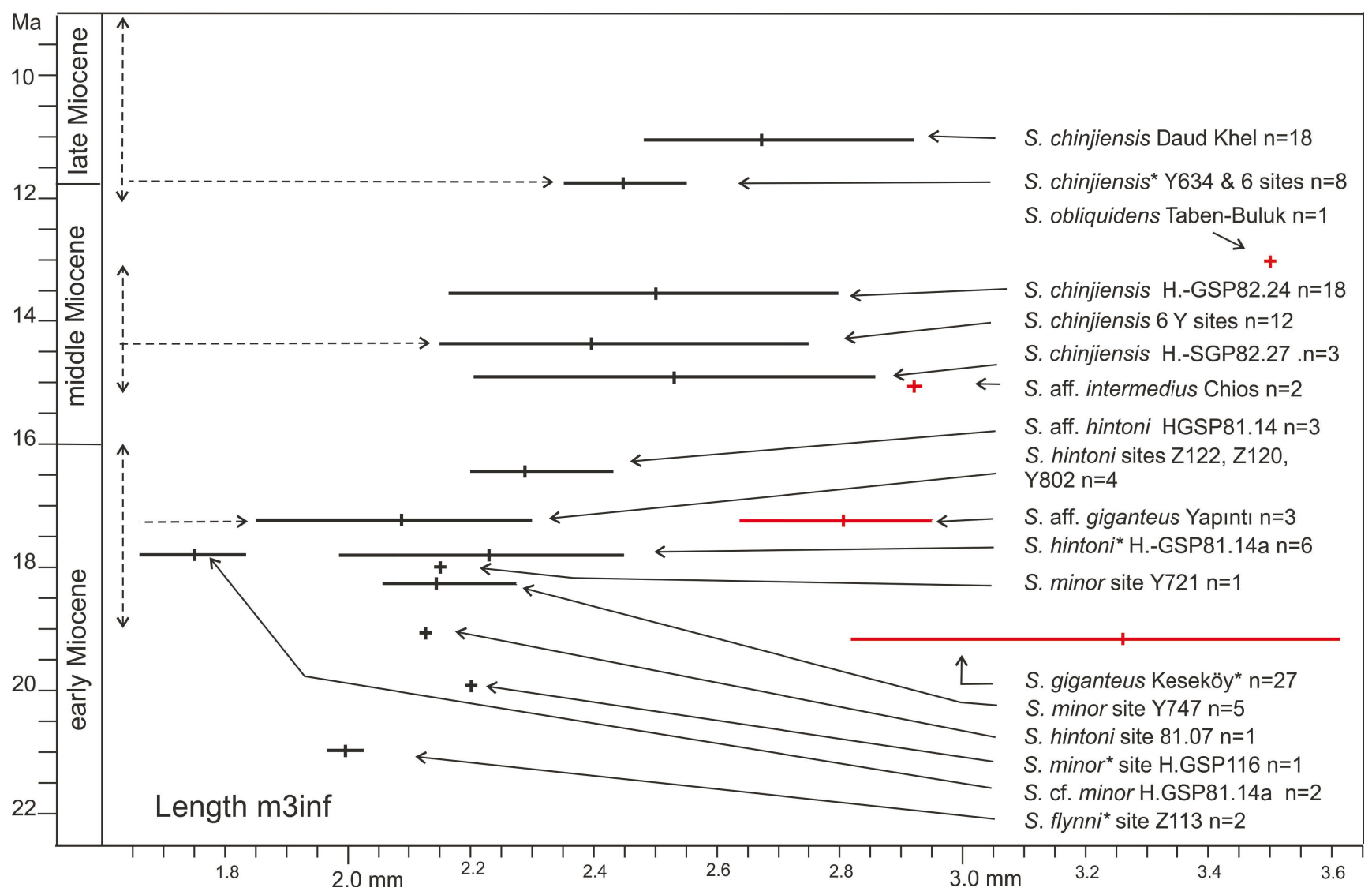

Text-fig. 13. Ranges of the length of the $\mathbf{m} 3$ based on data from the literature, see Text-fig. 12 for explanation.

rarely separated in the literature, though different in size: large assemblages have therefore very large ranges, whereas those of small assemblages are erratic.

The height of the crown has been measured in the Keseköy assemblage; for this measure, the height of the entoconid in the lower teeth and of the paracone in the upper teeth has been selected. Results are shown in Text- fig. 8 for different wear classes. Even in the large Keseköy assemblage, the number of un- or lightly worn cheek teeth is low.

Variation in morphology. Presence and length of the mesolophid in the dp4 is considered an important species-specific character. This feature varies strongly

Table 4. Measurements in mm of Sayimys aff. giganteus from Yapıntı and Horlak.

\begin{tabular}{|c|c|c|c|c|c|c|c|c|c|c|c|c|}
\hline & \multicolumn{4}{|c|}{ Length } & \multicolumn{4}{|c|}{ Anterior width } & \multicolumn{4}{|c|}{ Posterior width } \\
\hline & range & average & SD & $\mathbf{N}$ & range & average & SD & $\mathbf{N}$ & range & average & SD & $\mathbf{N}$ \\
\hline \multicolumn{13}{|c|}{ Yapıntı } \\
\hline DP3 & $0.72-0.77$ & 0.745 & - & 2 & - & 1.100 & - & - & $0.75-0.80$ & 0.775 & - & 2 \\
\hline DP4 & $1.86-1.97$ & 1.915 & - & 2 & $1.50-1.72$ & 1.633 & 0.117 & 3 & $1.63-1.64$ & 1.635 & - & 2 \\
\hline P4 & $1.20-1.34$ & 1.298 & 0.066 & 4 & - & - & - & - & $1.78-2.03$ & 1.928 & 0.108 & 4 \\
\hline M1 & $1.85-2.10$ & 1.997 & 0.086 & 6 & $1.94-2.17$ & 2.062 & 0.079 & 6 & $2.04-2.20$ & 2.095 & 0.057 & 6 \\
\hline M2 & $2.47-2.56$ & 2.510 & 0.046 & 3 & $2.50-2.52$ & 2.515 & 0.010 & 4 & $2.30-2.78$ & 2.408 & 0.208 & 5 \\
\hline M3 & $2.21-2.42$ & 2.330 & 0.108 & 3 & $2.33-2.43$ & 2.385 & 0.440 & 4 & $1.86-2.03$ & 1.948 & 0.059 & 6 \\
\hline dp4 & - & 2.540 & - & 1 & - & 1.100 & - & 1 & $1.35-1.46$ & 1.413 & 0.570 & 3 \\
\hline p4 & $1.38-1.61$ & 1.465 & 0.083 & 6 & - & - & - & - & $1.43-1.66$ & 1.508 & 0.085 & 6 \\
\hline m1 & $2.16-2.47$ & 2.291 & 0.113 & 9 & $1.51-1.83$ & 1.690 & 0.118 & 8 & $1.63-1.93$ & 1.799 & 0.109 & 8 \\
\hline m2 & - & 2.990 & - & 1 & $2.33-2.47$ & 2.400 & 0.099 & 2 & $2.26-2.48$ & 2.387 & 0.114 & 3 \\
\hline $\mathbf{m 3}$ & $2.64-2.95$ & 2.807 & 0.156 & 3 & $2.08-2.56$ & 2.333 & 0.155 & 7 & $2.02-2.30$ & 2.165 & 0.115 & 4 \\
\hline \multicolumn{13}{|c|}{ Horlak } \\
\hline M3 & - & - & - & - & - & - & - & - & - & 1.91 & - & 1 \\
\hline m1 & $2.23-2.32$ & 2.270 & - & 2 & $1.57-1.65$ & 1.615 & 0.034 & 4 & $1.67-1.83$ & 1.753 & 0.068 & 4 \\
\hline
\end{tabular}


among the 47 specimens of Sayimys from Keseköy; it can be complete, extending to the lingual tooth margin, relatively short, or absent. Absence of a mesolophid in a single or a few dp4 is thus not a species-specific character. A mesostylid is present in some dp4 from Keseköy either as a separate tubercle or recognizable as a thickening of the lingual end of the mesolophid.

The development of the anteroloph in P4, considered species-specific by some authors, occurs in the Keseköy assemblage with four character stages: a) well-developed, extending from the protocone to halfway the anterior tooth margin, paraflexus well-developed (Text-fig. 10, no 4203); b) short, extending to about a quarter of the anterior tooth margin, paraflexus short; c) anteroloph and paraflexus absent (Text-fig. 10, nos 4192 and 4193) and d) anteroloph absent, but with a small isolated cusp in front of the anteroloph (similar to YAP 1037 in Text-fig. 10). This suggests that this character has little value if only a few premolars are available. In general, the morphology of the P4 is rather variable (Text-fig. 10), and better not used as a species diagnostic element.

A variable character is the postero-labial cingulid of lower molars (Text-fig. 3). In the Keseköy material it is present in most $\mathrm{m} 1$ and $\mathrm{m} 2$, but variable in size. In general, it is better developed in $\mathrm{m} 1$ than in $\mathrm{m} 2$, and weak or absent in m3. A stylid on the postero-labial cingulid is present in 11 of the 18 p4 from Keseköy, and three specimens of Sayimys baskini (=S. minor) from Pakistan (Baskin 1996); it seems present in the single specimen of $S$. obliquidens from TabenBuluk and in ' $S$. perplexus' (= S. sivalensis) from Hari Talyangar, India (Wood 1937), but it has not been described in other species.

\section{Sayimys aff. giganteus LóPEZ-ANTOÑANZAS, SEn et SARAÇ, 2004 \\ Text-figs 9, 10}

Localities and formations. Yapıntı (Derinçay Formation) and Horlak 2 (Yeniçubuk Formation).

A ge range. MN 4, possibly also late MN 3 (Ünay et al. 2001, Sümengen et al. 1990).

Material and measurements. See Tab. 4.

D is cussion. The Yapıntı and Horlak material has been compared with early and middle Miocene species Sayimys flynni BASkin, 1996, S. minor DE Bruij, Hussain et LeINDERs, 1981, S. giganteus, S. obliquidens Bohlin, 1946, S. assarrarensis LóPEZ-AntoñanZAS et SEN, 2004 and $S$. intermedius (SEN et ThOMAS, 1979). The Yapıntı and Horlak material is smaller than $S$. giganteus or overlaps with the smaller specimens of Keseköy (Text-figs 12, 13). Sayimys flynni, S. minor, S. assarrarensis and $S$. intermedius are considerably smaller, but $S$. obliquidens is about of the same size. The dental morphology of the specimens from Yapintı and Horlak is very similar to the material from Keseköy, and therefore not described in detail. There are morphological differences in the dp4 and lower molars, in the mesolophid, with S. flynni, S. obliquidens and S. minor. Considering the size differences and agreement in dental morphology, the assemblages from Yapıntı and Horlak material are classified as $S$. aff. giganteus.
López-Antoñanzas et al. (2005) described Sayimys intermedius from the early Miocene of Chios (Greece). The Yapint1 dp4 resembles one of the three figured specimens from Chios in having a rounded, isolated anteroconid; the other two Chios specimens have an elongate transverse anteroconid. The Chios dp4 do not show a clear mesolophid, but the area of the mesolophid basin is less deep than the mesoflexid. Text-figs 12 and 13 suggest that the Chios material is too large to be included in S. intermedius; noteworthy is the long $\mathrm{m} 3$ from Chios. In dental morphology and size, the Chios material is close to that of Yapıntı, and should be classified as Sayimys aff. giganteus.

\section{Other formally named species of Sayimys}

R e marks. The oldest Sayimys species are known from the early part of the early Miocene, the youngest from the Pliocene. The ranges of the length of the dp4 and m3 relevant for the discussion of Sayimys assemblages are shown in chronological order (Text-figs 12, 13). The length of the DP4 and M3 show a very similar picture and are therefore not included. We follow Kordikova and de Bruijn (2001) in synonymizing Prosayimys BASkin, 1996 and Sayimys Wood, 1937. The geographical range of the genus is from Jebel Zelten, Libya in the west (Wessels et al. 2003) to Jianghu province in eastern China (Qui 2017). The genus is best known from the Siwaliks of Pakistan and India. Hereafter we discuss the formally named species of Sayimys, starting with the oldest known species with a typical Sayimys morphology.

\section{Sayimys flynni (BASKIN, 1996)}

Original combination. Prosayimys flynni BASKIN, 1996.

\section{Hol o ty pe. A left m3 no 295.}

Type locality. Z113 Zinda Pir dome, Pakistan; age of the site: late Oligocene, 23-26 Ma. See Lindsay and Flynn (2016) for correlation of this site to the GPTS scale.

Paratypes. 43 cheek teeth representing all tooth positions, unfortunately the $\mathrm{dp} 4$ is represented by two damaged and worn specimens only.

D is c u s s i on. These small teeth represent the oldest Sayimys species. The size ranges of $\mathrm{dp} 4$ and $\mathrm{m} 3$ are in Text-figs 12, 13. The badly worn and damaged dp4 figured in Baskin (1996) does not show a clear mesolophid, but it has been described as having one. All fifteen known lower molars have a well-developed mesolophid. The m1-2 shown by Baskin (1996: pl. 1, fig. D) has a cusp-shaped metaconid with a narrow connection to the protoconid, a feature seen as well in Sayimys hintoni n. sp. and S. chinjiensis (see below).

\section{Sayimys minor de BruiJn, Hussain et Leinders, 1981}

Hol oty pe. A left m1-2 no 313.

Ty p e loc a lity.H.-GSP116, Murree Formation near Banda Daud Shah, Pakistan; age of the site: 18.5-19.5 Ma (Baskin 1996).

$\mathrm{P}$ a r a t y p e s. One damaged dp4, one $\mathrm{m} 3$ and one M1-2. 
$\mathrm{D}$ i s c u s s i o n. A well-developed mesolophid is present in the dp4, but absent in the m1-2 and $\mathrm{m} 3$. The sizes of the specimens are like those of Sayimys flynni, or slightly larger.

This small collection of only four molars has been the subject of some discussion. Baskin (1996) suggested that the rather worn M1-2 is too large to fit in the same species as the other three teeth, without testing the homogeneity of the sample. The m1-2 and M1-2 of all large Sayimys populations have a large size variability if first and second molars are not separated (Tab. 2). This M1-2 may very well be a large second molar belonging to the same species as the other three teeth. Wang (1997) suggested that Sayimys minor could be a junior synonym of $S$. intermedius (Sen and Thomas 1979), because these species are similar in size, the only difference being the presence of a mesolophid in the single dp4 of $S$. minor and absence of this lophid in the single known dp4 of $S$. intermedius. But, as Baskin (1996: 41) mentioned: "persistence of a rodent species over 5 million years and 3,500 km distance would be highly unusual", and we therefore hesitate to follow Wang. LópezAntoñanzas and Sen $(2003,2004)$ subdivided the sample of $S$. minor from the type locality (only four teeth) into two or three species. The holotype (the m1-2, no 313) was included in S. intermedius (Sen and Thomas 1979) because "this molar cannot be differentiated from the equivalent tooth of $S$. intermedius". The dp4 and $\mathrm{m} 3$ were separated from the m1-2 for unknown reasons, and included into S. baskini LÓPEZ-ANTOÑANZAS et SEN, 2003, see below. It is not clear in this publication how to classify the fourth tooth in the sample from the type locality (the large M1-2). The clear remark by Munthe (1980) on the large variability in Sayimys was here completely forgotten or ignored. In our opinion, the assemblage from H.-GSP116 (Murree Formation) is homogenous, and there is no valid reason to split up the small collection of $S$. minor and include the holotype in $S$. intermedius, and thus to synonymize $S$. minor and S. intermedius.

\section{Sayimys baskini LóPEZ-AntoñanZas et SEN, 2003}

H o lo ty pe. An isolated right P4.

Ty pe 1 o c a lity. Y747, Potwar Plateau, Pakistan; age of the site: $18.3 \mathrm{Ma}$.

Additional material from the type locality. 52 cheek teeth, representing all tooth positions except DP3.

Other localities with Sayimys baskini. According to López-Antoñanzas and Sen (2003): site Y721 Potwar Plateau, Pakistan and site H.-GSP116 (Banda Daud Shah, the type locality of $S$. minor).

Discussion. The collections from the type locality Y747 and from Y721 were studied by Baskin (1996). He concluded that the specimens from these two sites may represent a new species, but refrained from naming it because awaiting additional material of Sayimys minor from its type locality in the Murree Formation at Banda Daud Shah. However, López-Antoñanzas and Sen (2003) did not have this restraint, and described the species $S$. baskini with type locality Y747, and included specimens from Y721. Not having studied the collection from Pakistan themselves,
López-Antoñanzas and Sen (2003) refer to Baskin (1996) for figures, description and measurements. The selection of the P4 as holotype is unfortunate, as it is morphologically the most variable element in large Sayimys populations. Regrettably, the published figures in Baskin (1996) are simplified line drawings, inadequate for a good evaluation of dental morphology. Baskin writes that the single unworn dp4 has a short mesolophid, its hypolophid is transversely directed, lower molars lack a mesolophid, the "M1-2 lack an anteroloph", thus the paraflexus is absent and protoand anteroloph are fused. Unfortunately, the only M1-2 of $S$. minor is rather worn, so the anteroloph is completely fused with the protoloph. We conclude that without more material from the type locality of $S$. minor that can ascertain the specific difference, $S$. baskini is a junior synonym of S. minor.

\section{Sayimys obliquidens BoHLIn, 1946}

Holotype. A part of a mandible with damaged and worn cheek teeth, no 268.

Type locality. The bad-lands near Taben-Buluk, Gansu Province, China; age of the site: middle (13 Ma?) Miocene. Taben-Buluk is now known as the Danghe area. The fossils described are surface finds from several locations in a tectonized area. Bohlin himself was unsure if all his material belonged to the same species, for a discussion, see Wang (1997), who concluded that all material can be included in the same species.

$\mathrm{Paratypes}$. If all material described by Bohlin is included: Tb 254 right upper tooth row, Tb 261 right upper tooth row, $\mathrm{Tb} 279 \mathrm{a}$ partial skull, $\mathrm{Tb} 279 \mathrm{~b}$ lower tooth row, TB 268 a left mandible with damaged molars.

Discussion. The geology of the Taben-Buluk (Danghe) area was studied by Wang et al. (2003), who were unable to fit Bohlin's Sayimys locations precisely into their sections, which span an age from 24 to $10 \mathrm{Ma}$. They state that three of the Bohlin localities are close to their fossil site Dh199913, correlated to the geomagnetic polarity timescale at $13 \mathrm{Ma}$, making the Taben-Buluk Sayimys obliquidens some 5 Ma younger than previously assumed. The material described and measured by Bohlin is of large size, in the lower-end of the range of $S$. giganteus, however, the $\mathrm{m} 3$ is in the high-end part of the range (Text-fig. 13). Considering the doubts about the homogeneity of the collection, and the exact location(s) and age of the type locality S. obliquidens is a nomen dubium, we therefore ring-fence the species name, that is, restrict it to its holotype.

The early Miocene material from Aktau (Kazakhstan) described by Kordikova and de Bruijn (2001) as Sayimys aff. obliquidens is much smaller. It shows a long mesolophid in the $\mathrm{m} 2$, but not in the $\mathrm{m} 1$, like in the holotype from TabenBuluk. A more appropriate classification for the material from Aktau is $S$. aff. minor.

\section{Sayimys intermedius (Sen et Thомаs, 1979)}

Original combination. Metasayimys intermedius Sen et Thomas, 1979.

H o 1 o t y p e. A part of a left mandible with dp4-m1-m2. 
Type locality. Al Jadidah (Saudi Arabia); age of the site: middle Miocene, 14 ? Ma.

$\mathrm{D}$ is c u s s i o n. This adequately described and figured species by López-Antoñanzas and Sen (2004) is known by its holotype only. Sayimys intermedius is small (Text-fig. 12), Baskin (1996) noted that the length of $\mathrm{m} 1$ is not $2.9 \mathrm{~mm}$ as described, but $2.09 \mathrm{~mm}$. A mesolophid is neither present on the dp4 nor on the two molars.

\section{Sayimys assarrarensis LóPEZ-ANTOÑANZAS et SEN, 2004}

H o l o t y p e. A fragmentary left maxilla with P4-M2.

P a r a ty pes. Some 18 isolated cheek teeth.

Type locality. As-Sarrar, Dam Formation, Saudi Arabia; assigned age of the site: later part of the early Miocene, 15-17 Ma.

D iscussion. This small species is similar in size to Sayimys intermedius. The As Sarrar locality is slightly older than the type locality of $S$. intermedius. The single reasonably preserved dp4 of $S$. assarrarensis shows a welldeveloped mesolophid and a slightly elongated anteroconid. Considering the large variation in dental morphology and size of large Sayimys assemblages, we consider S. assarrarensis a junior synonym of $S$. intermedius. More material is needed from the type localities to ascertain specific differences, if any.

\section{Sayimys sivalensis (Hinton, 1933)}

Original combination. Pectinator sivalensis Hinton, 1933.

Holotype. A left partial mandible with $\mathrm{m} 2$ and $\mathrm{m} 3$, see Black (1972) for a good illustration.

Type locality. Surface find near Chinji village (Pakistan), Chinji Formation; the age of the formation near Chinji village ranges from 14.3 to $10.8 \mathrm{Ma}$ (Johnson et al. 1985).

Discussion. Munthe (1980) allocated a fine collection of isolated Sayimys teeth from the upper part of the Chinji Formation near Daud Khel (age approximately 11-10 Ma; Jacobs et al. 1989) to S. sivalensis. He provided an emended diagnosis of $S$. sivalensis based on the Daud Khel assemblage.

Baskin (1996) recognized two species of Sayimys from the area near Chinji. He allocated the older relatively lowcrowned to $S$. sivalensis and described the younger relatively high-crowned as $S$. chinjiensis. This S. sivalensis material comes from thirteen small assemblages in the Kamlial and the lower Chinji Formations (age range 15.1-13 Ma), while eight small collections from the upper Chinji and Nagri Formations (age range 12.1-9.1 Ma) were included in $S$. chinjiensis. The Daud Khel assemblage described by Munthe was allocated to S. chinjiensis. Baskin (1996) considered the holotype of $S$. sivalensis primitive because of the position of its masseteric crest. He therefore assumed that it came from the lower Chinji beds. We consider Sayimys sivalensis a nomen dubium; its holotype is of unknown location and lacks diagnostic criteria, whereas the intraspecific variability of masseteric crest is not known. We therefore restrict the name $S$. sivalensis to the holotype, and create a new species to house the assemblages with relatively low-crowned molars.

\section{Sayimys hintoni $\mathrm{n} . \mathrm{sp}$. Text-figs 14, 15}

Holotype. An isolated dp4 no H.-GSP82.14a no 3001, Text-fig. 14; shown by de Bruijn et al. (1989) on pl. II, fig.10. Temporarily housed in Faculty of Earth Sciences, University Utrecht, the Netherlands.

Derivatio no min is . Named after M. A. C. Hinton who described Pectinator sivalensis.

Type locality. H.-GSP81.14a, lower Manchar Formation, Sind, Pakistan; early Miocene, age approximately $18 \mathrm{Ma}$ (Wessels 2009).

O c c u r r e n c e s . H.-GSP82.06, H.-GSP82.07 and H.GSP82.14. Lower Manchar Formation, Sind, Pakistan; early Miocene (approximate range 19.5-16.3 Ma; Wessels 2009).

Assemblages from Z120 and Z122 (Baskin 1996).

Material and measurements. See Tab. 5 for type locality H.-GSP81.14a, Tab. 6 for locality H.-GSP81.07, Tab. 7 for locality H.-GSP81.06. See the table in de Bruijn et al. (1989: 196). Text-fig. 16 shows length-width scatter diagrams of the molars of Sayimys hintoni and S. cf. minor.

Diagnosis. Sayimys hintoni is relatively small. The anteroconid of the dp4 is elongate, ovoid in shape, and tends to form low ridges to metaconid and protoconid, anterolophid absent. A long confluent diagonal ridge is formed by the protoconid, ectolophid, hypolophid and entoconid. The metalophulid of most $\mathrm{m} 1-3$ has a narrowconstricted connection to the protoconid (arrow in Text-fig. 14). In upper molars the para- and metaflexus are short and poorly developed.

Differential diagnosis. Sayimys hintoni is larger than S. flynni and S. intermedius, roughly similar $S$. minor and S. baskini, but smaller than S. obliquidens and $S$. giganteus; it is slightly smaller and partially overlapping in size with $S$. chinjiensis. It differs from S. flynni, S. minor, S. obliquidens and $S$. intermedius in the absence of a mesolophid. Its dp4 is different from $S$. flynni, S. minor, $S$. obliquidens and $S$. intermedius in the long, smooth and confluent diagonal lophid formed by protoconid, ectolophid, hypolophid and entoconid, and in the narrow connection between protoconid and metaconid. It differs from $S$. intermedius and $S$. chinjiensis in the shape of the anteroconid. Assemblages of $S$. chinjiensis tend to have dp4 and lower molars with more oblique lophids, whereas para- and metaflexus in the upper molars are more reduced, or absent. In contrast to $S$. hintoni, almost all $\mathrm{dp} 4$ of $S$. chinjiensis have a well-developed anterolophulid.

Discussion. In the Sayimys assemblage of H.GSP81.14a, type locality of S. hintoni, the two smallest lower molars are subject to discussion. The outline of the teeth suggests that they could be $\mathrm{m} 1$ or $\mathrm{m} 3$. The lack of a posterior interdental facet indicates $\mathrm{m} 3$; if so, these $\mathrm{m} 3$ are too small to fit the assemblage of $S$. hintoni $\mathrm{n}$. sp. Text-fig. 16 
Table 5. Measurements in mm of Sayimys hintoni n. sp. from the type locality H.-GSP81.14a (lower Manchar Formation, Sind, Pakistan) and of $S$. cf. minor from the same site.

\begin{tabular}{|c|c|c|c|c|c|c|c|c|}
\hline & \multicolumn{4}{|c|}{ Length } & \multicolumn{4}{|c|}{ Anterior width } \\
\hline & range & average & SD & $\mathbf{N}$ & range & average & SD & $\mathbf{N}$ \\
\hline \multicolumn{9}{|c|}{ S. hintoni } \\
\hline D4 & $1.62-1.88$ & 1.763 & 0.101 & 7 & $1.50-1.80$ & 1.667 & 0.104 & 7 \\
\hline P4 & $1.20-1.42$ & 1.290 & 0.080 & 6 & $1.80-2.07$ & 1.920 & 0.110 & 6 \\
\hline M1-2 & $1.79-2.17$ & 2.024 & 0.142 & 8 & $2.02-2.36$ & 2.188 & 0.110 & 8 \\
\hline M3 & $1.89-2.21$ & 2.018 & 0.136 & 4 & $2.13-2.40$ & 2.298 & 0.116 & 4 \\
\hline d4 & $1.93-2.30$ & 2.133 & 0.188 & 3 & $1.18-1.37$ & 1.305 & 0.090 & 3 \\
\hline p4 & $1.51-1.58$ & 1.545 & - & 2 & $1.51-1.54$ & 1.525 & - & 2 \\
\hline m1-2 & $1.85-2.50$ & 2.174 & 0.217 & 7 & $1.59-2.22$ & 1.844 & 0.229 & 7 \\
\hline m3 & $1.98-2.45$ & 2.235 & 0.197 & 6 & $1.92-2.29$ & 2.092 & 0.159 & 5 \\
\hline \multicolumn{9}{|c|}{ S. cf. minor } \\
\hline M3 & - & 1.700 & - & 1 & 1.92 & - & - & 1 \\
\hline m3 & $1.66-1.85$ & 1.755 & - & 2 & 1.67 & $1.42-1.92$ & - & 2 \\
\hline
\end{tabular}

Table 6. Measurements in mm of Sayimys hintoni n. sp. from H.-GSP81.07 (lower Manchar Formation, Sind, Pakistan).

\begin{tabular}{lcccccccc}
\hline & \multicolumn{3}{c}{ Length } & & \multicolumn{3}{c}{ Width } \\
\cline { 2 - 3 } \cline { 7 - 8 } \cline { 6 - 8 } d4 & range & mean & $\mathbf{N}$ & & range & mean & $\mathbf{N}$ \\
$\mathbf{m 1 - 2}$ & $1.80-1.97$ & 1.89 & 2 & & $1.06-1.11$ & 1.09 & 2 \\
$\mathbf{m 3}$ & $2.05-2.38$ & 2.22 & 2 & & $1.79-2.01$ & 1.90 & 2 \\
\hline
\end{tabular}

compares the Sayimys molars of locality H.-SGP14a with the outline of the size clouds of $\mathrm{m} 1$ and $\mathrm{m} 2-3$ from the large sample of $S$. chinjiensis from H.-SGP82.24. The two sizecloud outlines are indicative of the size and variation of $\mathrm{m} 1$ and $\mathrm{m} 2-3$, and demonstrate that the two $\mathrm{m} 3$ identified as Sayimys cf. minor are much smaller than those of S. hintoni n. sp. The molars are the smallest m3 of Sayimys known (Text-fig. 13); these differ in morphology from $S$. hintoni in their short V-shaped mesoflexid and a triangular metalophid (Text-fig. 14). We have also identified a small unworn M3 that could be included in $S$. cf. minor (Text-figs 15, 16). The M3 of Sayimys species have the same length and width as the M2 (Text-figs 5, 17), therefore this small M3 does not fit in with the group of probable M3 of $S$. hintoni in Text-fig. 16.
Baskin (1996) compared 34 isolated cheek teeth from five sites, two in the Zinda Pir area (Z120 and Z122) and three on the Potwar Plateau (Y591, Y592 and Y802), to Sayimys intermedius. The measurements of these are not presented for each location separately, but have been lumped into one table (Baskin 1996: tab. 4). The anteroconid of the four dp4 in this collection is ovoid in shape (Baskin 1996: fig. 5h); the entoconid is cuspate with a narrow connection to the protoconid (Baskin 1996: fig. 5i, j, k) and the mesoflexid is long and forward directed, the paraflexus and metaflexus of M1-2 are short, with wear the paraflexus persists longer than the metaflexus. These teeth are morphologically and in size like Sayimys hintoni, and are labelled S. hintoni in Text-figs 12, 13.

\section{Sayimys chinjiensis BASKIN, 1996}

H o l o ty pe. Left mandible fragment with p4-m1.

$\mathrm{P}$ a r a ty pes. Two P4, one M1-2, one p4, one m3.

Type locality. Site Y634, upper Chinji Formation, Potwar Plateau, Pakistan; age of the site: 11.9 Ma.

Other sites. Eight sites in the upper Chinji and Nagri Formations (age range 12.1-9.1 Ma; see Baskin 1996), Daud Khel, upper Chinji Formation, age according to Jacobs et al. (1989) is 11-10 Ma (see Munthe 1980).

Table 7. Measurements in mm of Sayimys hintoni n. sp. from H.-GSP81.06 (lower Manchar Formation, Sind, Pakistan).

\begin{tabular}{|c|c|c|c|c|c|c|c|c|}
\hline & \multicolumn{4}{|c|}{ Length } & \multicolumn{4}{|c|}{ Width } \\
\hline & range & mean & SD & $\mathbf{N}$ & mean & range & SD & $\mathbf{N}$ \\
\hline DP4 & $1.63-1.70$ & 1.663 & 0.036 & 3 & 1.563 & $1.52-1.60$ & 0.040 & 3 \\
\hline M1-2 & $1.78-2.19$ & 1.993 & 0.186 & 4 & 2.270 & $2.10-2.45$ & 0.171 & 4 \\
\hline M3 & $1.77-1.96$ & 1.843 & 0.102 & 3 & 2.087 & $1.94-2.25$ & 0.156 & 3 \\
\hline p4 & $1.31-1.32$ & 1.315 & - & 2 & 1.265 & $1.22-1.31$ & - & 2 \\
\hline m1-2 & $2.00-2.23$ & 2.078 & 0.104 & 4 & 1.770 & $1.64-20.2$ & 0.174 & 4 \\
\hline m3 & $1.90-1.95$ & 1.925 & - & 2 & 1.675 & $1.64-1.71$ & - & 2 \\
\hline
\end{tabular}




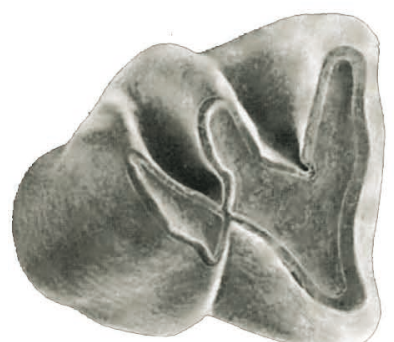

m3: 3111

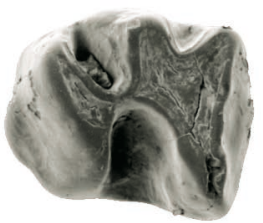

m3: H.-GSP81.14a-3033 Sayimys cf. minor

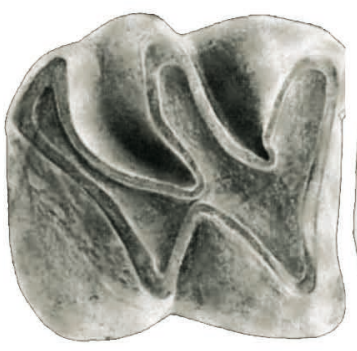

m2: 3086

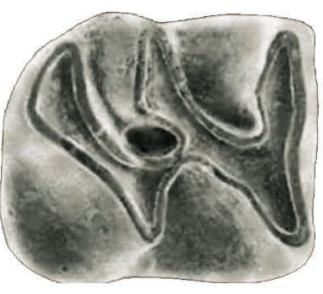

$\underline{m 1: 3061}$

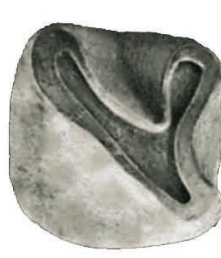

p4: 3057

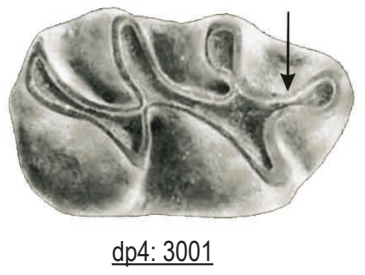

dp4: 3001

Sayimys chinjiensis H.-GSP82.24

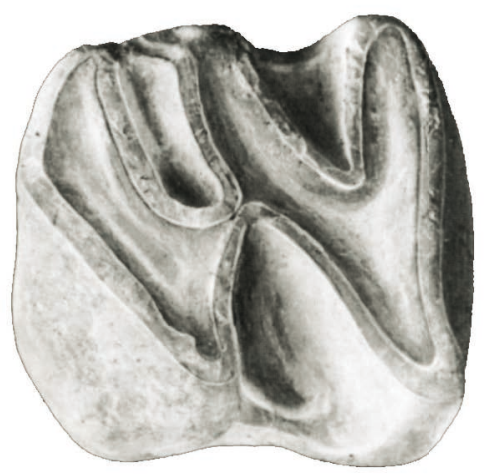

Sayimys cf. giganteus

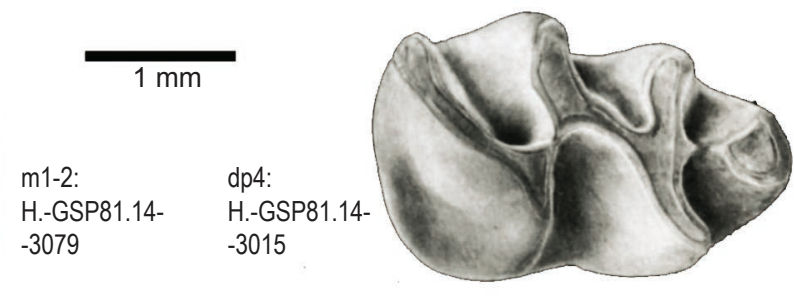

Sayimys cf. giganteus

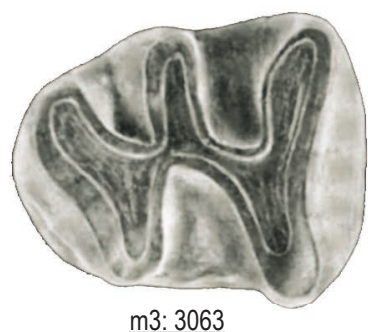

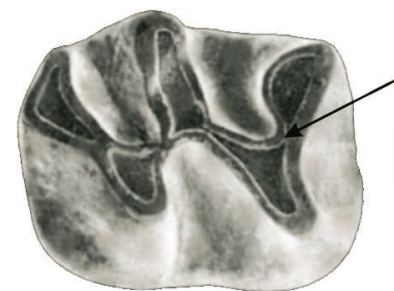

m2: 3032

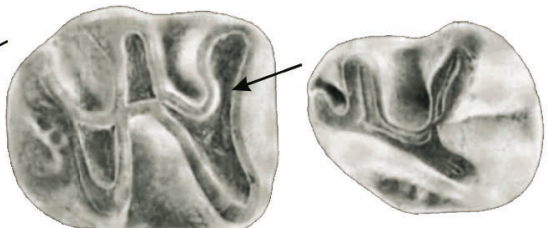

p4: 3011

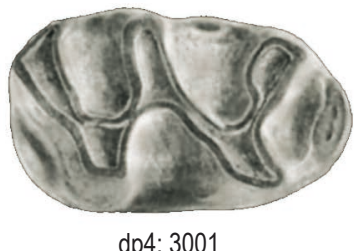

dp 4: 3001

Sayimys hintoni n. sp. H.-GSP.14a

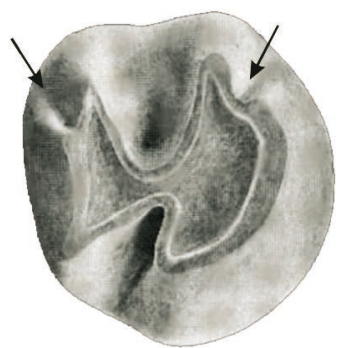

M3: 3253

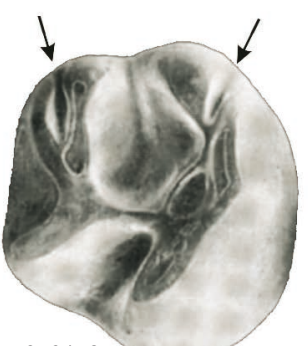

M3: 3152

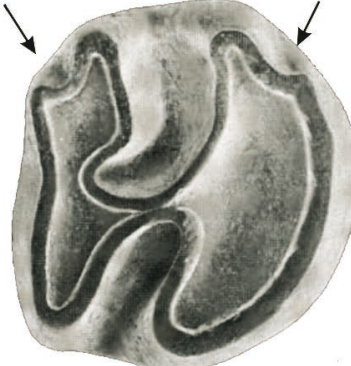

M1-2: 3201

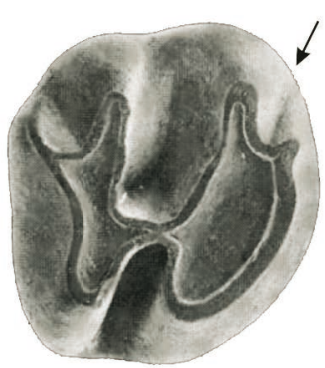

M1-2: 3224

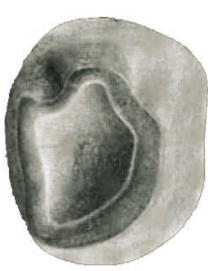

P4: 3181

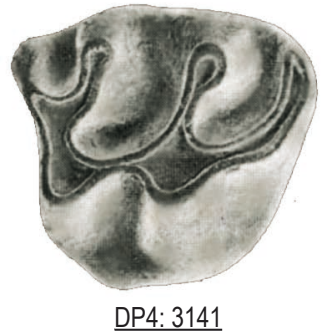

Sayimys chinjiensis H.-GSP82.24

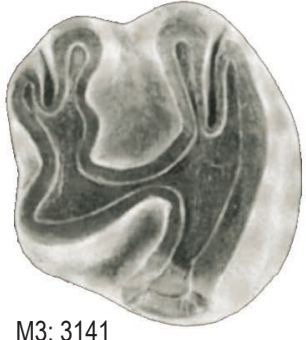

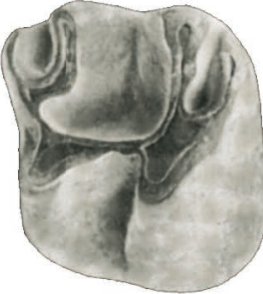

M1-2: 3131

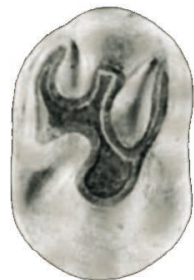

P4: 3112

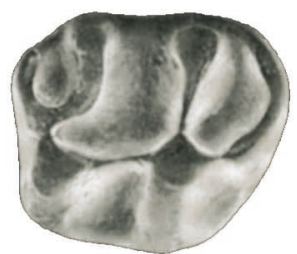

DP4: 3083

Sayimys hintoni n. sp. H.-GSP81.14a

Text-fig. 14. Cheek teeth of Sayimys hintoni n. sp. and S. cf. minor from H.-GSP81.14a, S. cf. giganteus from H.-GSP81.14 and S. chinjiensis from H.-GSP82.24. 


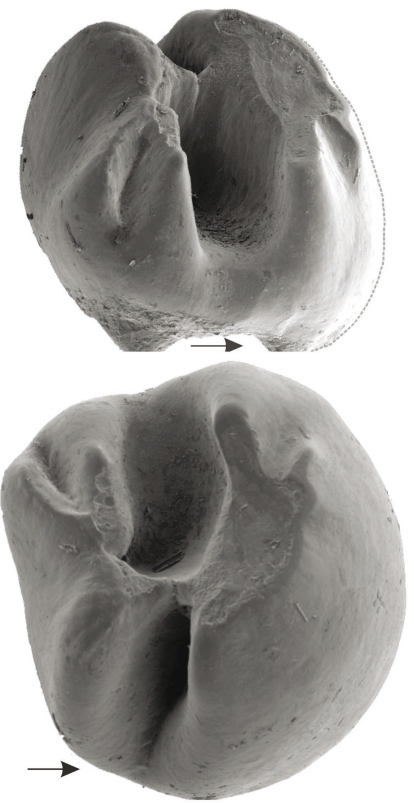

a: M1-2: 3201
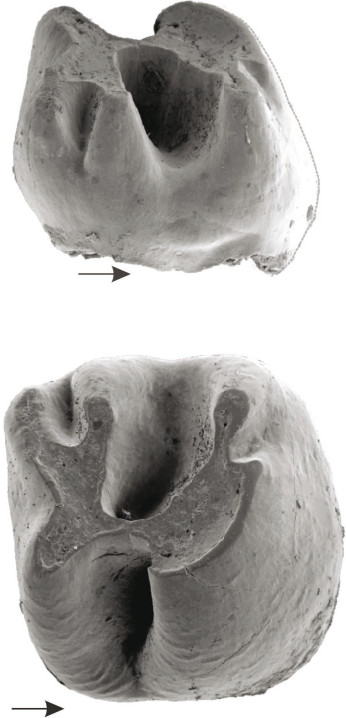

b: $M 1-2: 2432$
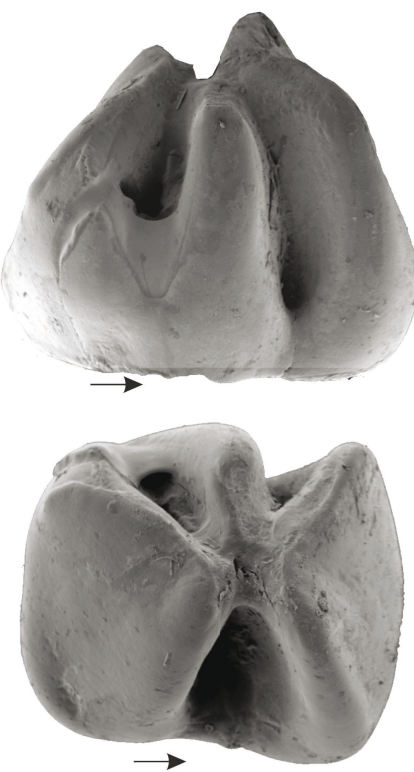

c: m1-2: 3095
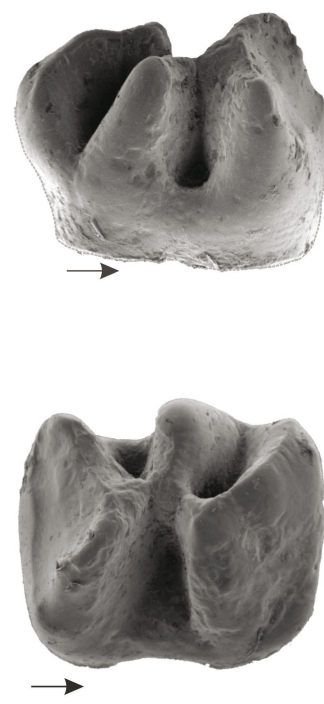

d: m1-2: 3066

Sayimys chinjiensis H.-GSP82.24
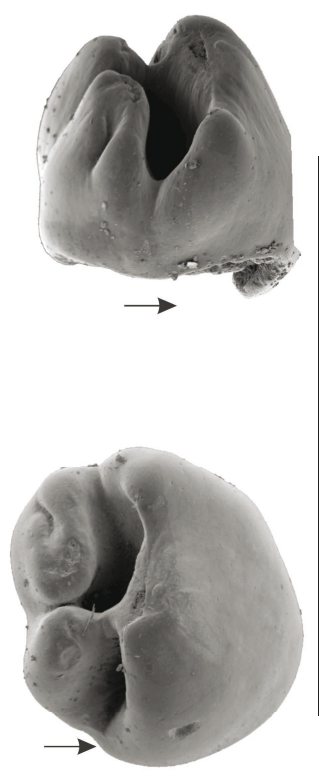

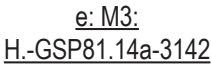

S. cf. minor

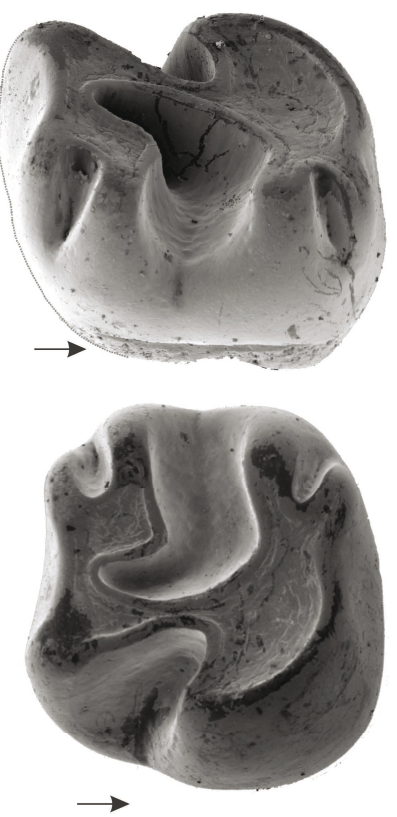

f: M1-2: 3036

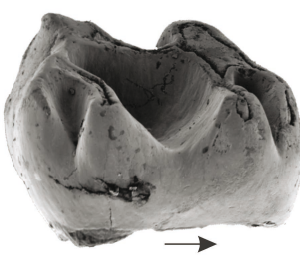

$1 \mathrm{~mm}$

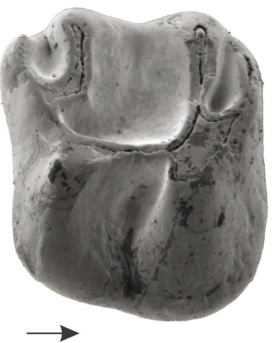

g: M1-2: 3031
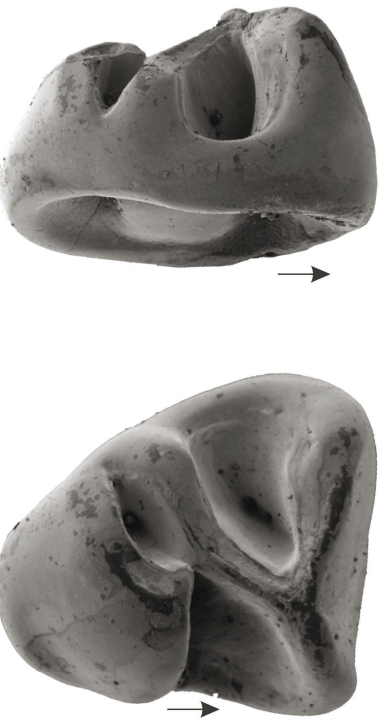

h: m3: 3071
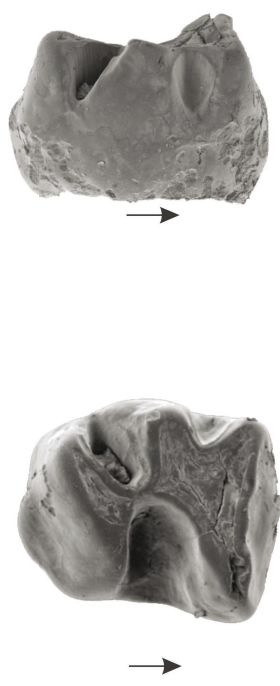

i: $\mathrm{m3}:$

H.-GSP81.14a-3133

S. cf. minor

Text-fig. 15. Lightly worn molars of Sayimys hintoni n. sp. (f, g, h) and S. cf. minor (e and i) from locality H.-GSP81.14a and S. chinjiensis from H.-GSP82.24 (a, b, c, d). Upper molars: occlusal surfaces and labial sides, lower molars occlusal surfaces and lingual sides. Side views horizontally-mirrored, anterior indicated by arrows.

H.-GSP107, Chinji Formation near Banda Daud Shah (Wessels et al. 1982), age 14 Ma (Jacobs et al. 1989, Wessels 2009).

H.-GSP82.24, lower Manchar Formation, age 13.5 Ma (Wessels 2009).

Original diagnos is. "Moderately high crowned cheek teeth with relatively thick enamel base. The paraflexus is absent on the upper molars. A short metaflexus is present on the M1 and M2, it is usually absent on M3. On m3 the metastriid [ = metaflexid in lingual view] extends relatively deeply on the internal face" (Baskin 1996).

Emended diagnosis. dp4 with rounded anteroconid and well-developed anterolophulid in medial position. In dp4 and molars, the mesolophid is absent, hypolophid is oblique, and the metalophulid-protoconid connection is narrow. A confluent, long diagonal lophid is formed by protoconid, ectolophid, hypolophid and entoconid in the dp4. Lophids of the lower molars are 

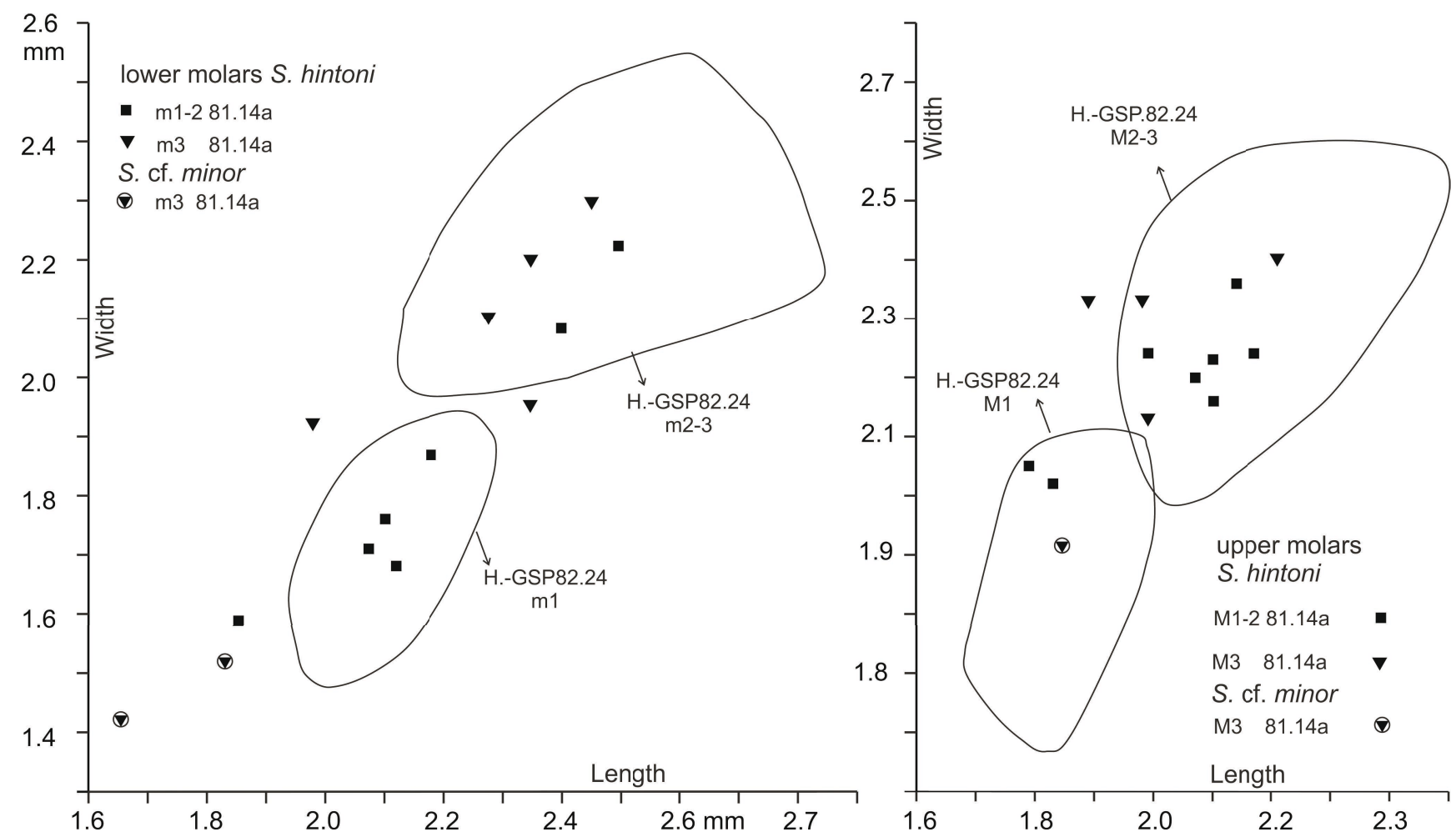

Text-fig. 16. Length-width scatter diagram of isolated molars of Sayimys hintoni $\mathrm{n}$. sp. and $S$. cf. minor from sites H.-SGP 81.14a (lower Manchar Formation, Sind, Pakistan) with the size-cloud outlines of molars of the large sample of $S$. chinjiensis from H.-GSP.24 shown in Text-fig. 17.

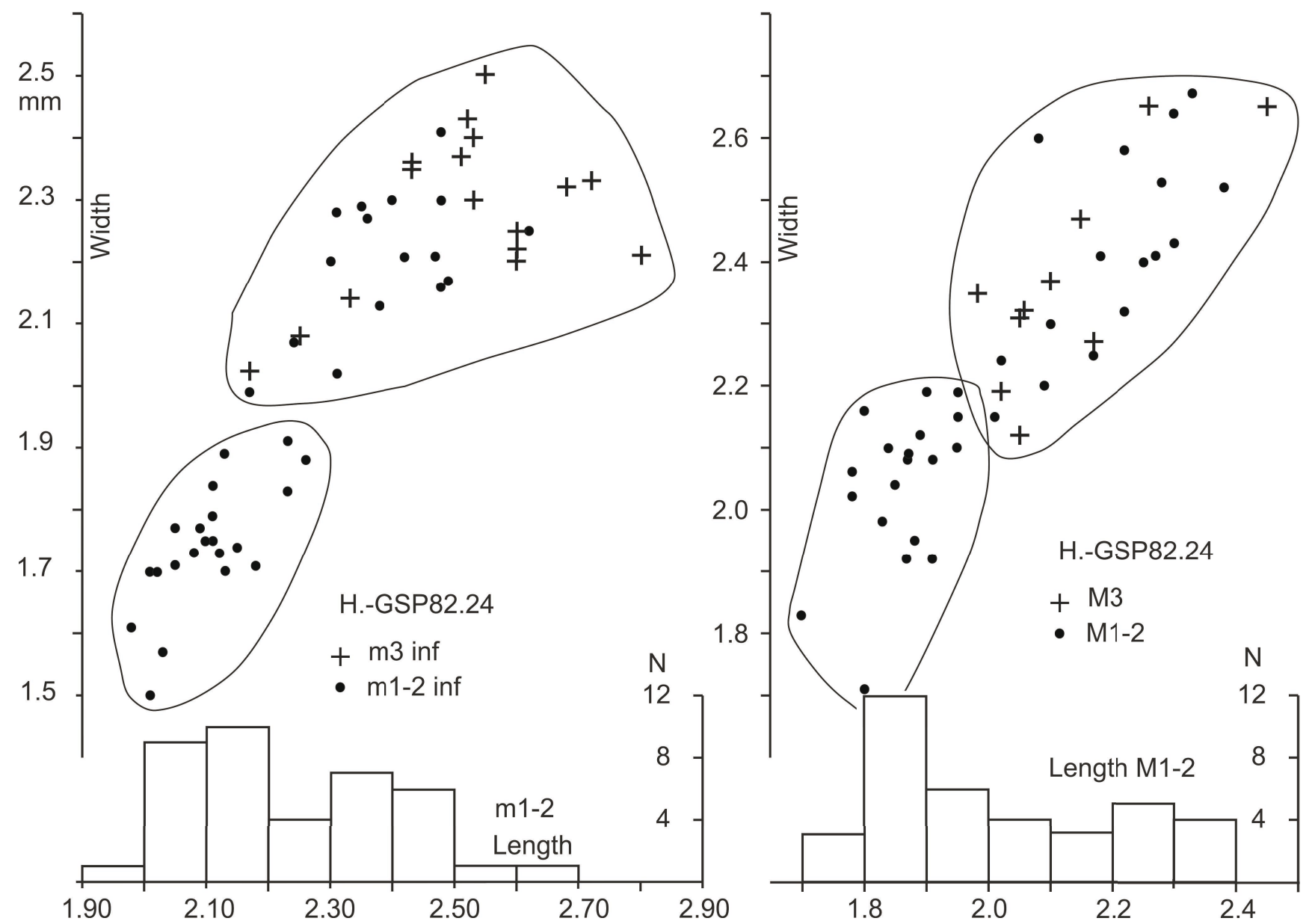

Text-fig. 17. Length-width scatter diagram and histograms of isolated molars of Sayimys chinjiensis from locality H.-SGP82.24 in the lower Manchar Formation (Sind, Pakistan). 
Table 8. Measurements in mm of Sayimys chinjiensis from H.-GSP82.24 (lower Manchar Formation, Sind, Pakistan). The width is the maximum width.

\begin{tabular}{|c|c|c|c|c|c|c|c|c|}
\hline & \multicolumn{4}{|c|}{ Length } & \multicolumn{4}{|c|}{ Posterior width } \\
\hline & range & average & SD & $\mathrm{N}$ & range & average & SD & $\mathrm{N}$ \\
\hline DP4 sup & $1.65-2.05$ & 1.855 & 0.089 & 26 & $1.45-2.02$ & 1.704 & 0.108 & 26 \\
\hline P4 sup & $1.02-1.38$ & 1.196 & 0.142 & 5 & $1.53-1.96$ & 1.762 & 0.174 & 5 \\
\hline M1 sup & $1.70-1.95$ & 1.861 & 0.062 & 21 & $1.71-2.19$ & 2.028 & 0.122 & 21 \\
\hline M2 sup & $2.01-2.38$ & 2.200 & 0.113 & 16 & $2.15-2.67$ & 2.416 & 0.163 & 16 \\
\hline M3 sup & $1.98-2.45$ & 2.129 & 0.139 & 10 & $2.12-2.65$ & 2.370 & 0.196 & 10 \\
\hline dp4 inf & $1.95-2.50$ & 2.274 & 0.132 & 24 & $1.06-1.56$ & 1.375 & 0.124 & 24 \\
\hline p4 inf & $1.26-1.69$ & 1.493 & 0.130 & 12 & $1.24-1.75$ & 1.521 & 0.126 & 12 \\
\hline $\mathrm{m} 1 \mathrm{inf}$ & $1.98-2.26$ & 2.104 & 0.077 & 21 & $1.50-1.91$ & 1.742 & 0.1 .01 & 21 \\
\hline $\mathrm{m} 2 \mathrm{inf}$ & $2.05-2.62$ & 2.370 & 0.133 & 18 & $1.99-2.41$ & 2.204 & 0.112 & 16 \\
\hline m3 inf & $2.17-2.80$ & 2.498 & 0.164 & 18 & $2.02-2.50$ & 2.272 & 0.130 & 17 \\
\hline
\end{tabular}

strongly diagonal. Upper molars have poorly developed paraflexus and metaflexus, disappearing early with wear; these flexids may be totally absent in molars of assemblages from the younger Nagri Formation.

Discussion. Unfortunately, the illustrations in Baskin (1996) are inadequate. Moreover, not all tooth positions are known from the type locality. In addition to the type locality, Baskin allocated 75 specimens from eight localities to this species. The eight assemblages are thus small; the largest has 17 teeth, the smallest two. The eight sites are in the upper Chinji Formation and overlying Nagri Formation, and range in age from 12.1 to 9.1 Ma. Baskin (1996) defined this species as having no paraflexus (and thus no anteroloph) in the upper molars, and in being more hypsodont than those of Sayimys sivalensis. It appears from the description that the paraflexus is absent in molars from the Nagri Formation. Baskin assigned the large collection from Daud Khel (described by Munthe 1980 as S. sivalensis) to $S$. chinjiensis.

Using measurements obtained from Baskin, LópezAntoñanzas and Sen (2003) plotted the height of M1-2 and $\mathrm{m} 3$, and observed that the highest M1-2 are those classified in Sayimys chinjiensis, but the overlap with S. sivalensis is large; the $\mathrm{m} 3$ do not show a difference in height. The differences between the assemblages allocated to the two species are relatively small, and considering the large variability in Sayimys species, small samples are difficult to allocate. López-Antoñanzas and Sen (2003) therefore synonymized Sayinys chinjiensis with S. sivalensis. This decision is unfortunate, because $S$. chinjiensis has a clear type locality and S. sivalensis does not. Moreover, the holotype of $S$. sivalensis is not considered diagnostic. We therefore do not follow López-Antoñanzas and Sen, and maintain $S$. chinjiensis and restrict the name $S$. sivalensis to its holotype (see above). With the inclusion of the Daud Khel assemblage in Sayimys chinjiensis, this species is morphologically well defined. We also include the large assemblage from H.GSP82.24 from the lower Manchar Formation (described by de Bruijn et al. 1989, illustrated here in Text-figs 14, 15), and from site H.-GSP107 Banda Daud Shah (Wessels et al. 1982) in Sayimys chinjiensis. Text-fig. 17 shows length- width scatter diagrams of $S$. chinjiensis from H.-GSP82.24, and Tab. 8 the measurements.

Our designation H.-GSP14a in the lower Manchar Formation as the type locality of $S$. hintoni n. $\mathrm{sp}$. is pragmatic. The material from this site is well described and figured (de Bruijn et al. 1989), and the morphotypes are sufficiently different from the younger $S$. chinjiensis and the older S. baskini, S. minor to allow classification of all but the smallest assemblages.

\section{Sayimys perplexus Wood, 1937, S. badauni VASISHAT, 1985 and $S$. sihingensis QIU, 2017}

C o m me n t s. Baskin (1996) remarked that Sayimys is rare in Siwalik deposits younger than 9 Ma. Sayimys perplexus WoOD, 1937 with type locality near Haritalyangar (India) in the Nagri Formation (age approx. 7 Ma; Baskin 1996), has been considered a junior synonym of $S$. sivalensis by some specialists (e.g. Munthe 1980). Sayimys badauni was described by Vasishat (1985) from the Pliocene Tatrot Formation, near Badauni (India). See López-Antoñanzas and Sen (2003) and López-Antoñanzas and Knoll (2011) for some remarks on these two poorly known species. These two occurrences extend the stratigraphic range of Sayimys in the Siwaliks into the Pliocene. The recently described Sayimys sihingensis (Qiu 2017) from the later part of the early Miocene, Jiangsu Province (China) is based on very limited material. This record extends the geographical range of the genus to eastern China. Judging from the figures, $S$. sihingensis seems more hypsodont than the time-equivalent material from Pakistan.

\section{Evolutionary trends and biogeography}

The best succession of Sayimys is known from the early and middle Miocene of Pakistan. After a discussion of the chronology of the faunas in Pakistan with ctenodactylids (Text-fig. 18), the evolutionary trends observed in this succession are briefly discussed. The localities with fossil rodents from the Potwar Plateau and the Zinda Pir Dome have been correlated to the magnetostratigraphic time scale, and their ages can be expressed in Ma (Text-fig. 


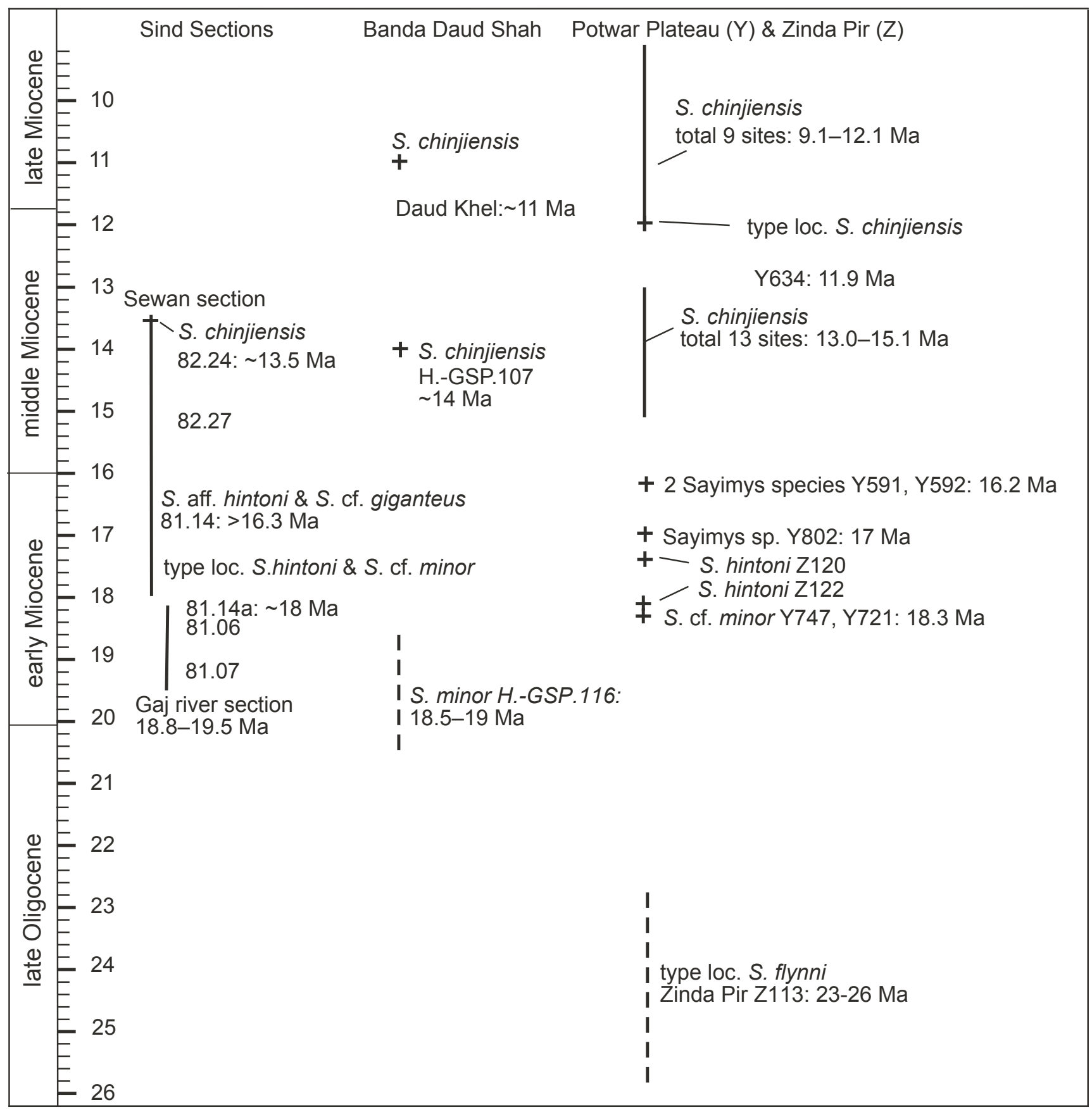

Text-fig. 18. Chronostratigraphic table showing the positions of the Sayimys-bearing localities in three areas in Pakistan. In the Sind Province (lower Manchar Formation) are the localities in the Sehwan section H.-GSP82.14, -82.27, -82.14, and -82.14a; in the Gaj River section are H.-GSP81.06 and -81.07. In the Banda Daud Shah area are the localities of Daud Khel, H.-GSP107 and the site at the base of the Murree Formation H.-GSP116. On the Potwar Plateau and in Zinda Pir are the Y and Z localities.

18). Magnetostratigraphic work has not been carried out in the Sind and Banda Daud Shah areas, but biostratigraphic correlations with the Zinda Pir and Potwar Plateau allowed us to fit these sites into the chronology of the Potwar Plateau and Zinda Pir Dome. For the construction of Text-fig. 18, Lindsay et al. 2005, Lindsay and Flynn (2016), Métais et al. (2009), Wessels and de Bruijn (2001), Baskin (1996) and Jacobs et al. (1989) were consulted.

A size increase can be observed from the oldest known species Sayimy flynni (age approx. 23-26 Ma) to $S$. chinjiensis (age approx. $12 \mathrm{Ma}$ ) as is shown in Text-figs 12 and 13, however, the increase does not seem regular.
Crown height correlates strongly with the length of the molars, but a relative increase in crown height from S. flynni to $S$. chinjiensis is difficult to demonstrate, due to lack of measurements of unworn teeth. However, when comparing M1-2 with the same stage of wear from an assemblage of $S$. hintoni with those from an assemblage of S. chinjiensis, those of the younger assemblage are higher crowned (de Bruijn et al. 1989).

The oldest assemblage Sayimys flynni has a mesolophid on dp4, m1-2 and a well-developed long paraflexus on upper molars; younger assemblages of Sayimys have lost the mesolophid. 
Sayimys minor (= S. baskini) is small. The single available P4 has no anteroloph, however, this feature is variable in Sayimys assemblages. Further, Baskin (1996) states that most M1-2 have no anteroloph, that is to say, the paraflexus is poorly developed or absent, suggesting that the simplification of the upper molars started with $S$. minor. This simplification (reduction of the paraflexus and metaflexus) continued in Sayimys hintoni and S. chinjiensis. In the upper molars, in particular the M3, the paraflexus is absent or not much more than a grove on the antero-labial side of the tooth, and thus the anteroloph has disappeared. The metaflexus is poorly developed as well, even in lightly worn specimens, leaving the posteroloph as a small spur.

Another morphological trend is in the development of the anteroconid on the dp4. That of Sayimys hintoni is elongate, or crescent shaped with no, or relatively rare presence of an anterolophulid; that of $S$. chinjiensis is rounded, with mostly a well-developed anterolophulid. Further in the dp4, the hypolophid, ectolophid, protoconid and anterolophulid developed into a prominent confluently-curved oblique ridge. A similar development is seen in the molars, for which de Bruijn et al. (1989) showed that the lophids of m1-2 of $S$. chinjiensis in site H.-GSP82.24 are more oblique than those of the older S. hintoni in sites H.-GSP81.14 and -81.14a.

Baskin (1996) suggested the presence of two species of Sayimys in the Potwar plateau and Zinda Pir sites during the latest part of the early Miocene (shown in Text-fig. 18 as S. cf. minor and Sayimys sp.); the sites Y991 and Y592 have two species that have a small size difference, and are supposed to differ in morphology. All these Sayimys assemblages consist of a few isolated cheek teeth only. The intraspecific variation is thus unknown; this, combined with poor illustrations and the merged size tables in Baskin hampers a thorough evaluation.

De Bruijn et al. (1989) described from site H.-GSP14 (Text-fig. 18) dp4 and m1-2 that are far too large to fit the assemblage of Sayimys aff. hintoni from that location. These teeth are indicated on Text-fig. 12 and illustrated in Text-fig. 14 as Sayimys cf. giganteus, because they are similar in size to $S$. giganteus, but the morphology of the anteroconid in the $\mathrm{dp} 4$ differs from that of $S$. giganteus in showing a tendency to form an anterolophulid. The small $S$. cf. minor occurs together with $S$. hintoni n. sp. in H.-GSP81.14a (Text-fig. 14). The two assemblages H.-GSP81.14a and H.-GSP81.14 thus clearly show the presence of at least three roughly contemporaneous Sayimys species in the early Miocene of Pakistan.

The assemblages Sayimys hintoni and S. chinjiensis from the Siwaliks differ from contemporaneous Sayimys assemblages from Turkey, Greece, Saudi Arabia and Northern Africa in some subtle, but clearly stable, morphological features. The dp4 of western assemblages do not have an anterolophulid; the dp4 and lower molars lack the constriction of the metalophulid where it connects to the ectolophid. In the dp4 of the Siwaliks species, the hypolophid tends to be diagonally oriented, and together with the ectolophid and the protoconid, form a confluent curved ridge; the $\mathrm{m} 1$ and $\mathrm{m} 2$ shows this character as well, but less clearly. This is not seen in the western species, where in particular in the dp4, the hypolophid tends to be transversely oriented. Siwalik species show a trend to reduce paraflexus and metaflexus in the upper molars, in particular in the M3. This reduction is not seen in western assemblages. Caution is needed, because apart from Keseköy and Yapıntı, the western assemblages are small, and not all tooth positions are known.

\section{Conclusions}

The large collection of the high-crowned ctenodactylid Sayimys giganteus from the early Miocene site of Keseköy consists of at least 30 individuals; that of $S$. aff. giganteus from Yapint1 suggests of a minimum number of five individuals. The size of the collections of isolated cheek teeth permitted the differentiation of all molar positions. The overall dental morphology appears to be stable, but some characters, such as the mesolophid in dp4, used for species identification appear to show large intra-specific variation. The fourth premolars also show a rather variable morphology. The size of the cheek teeth (length, width and height) shows large ranges. The large number of cheek teeth allowed the calculation of reliable coefficients of variation. These can be used to estimate size ranges of small assemblages. Dental pattern and height of Sayimys cheek teeth change with wear; the large collection of Sayimys giganteus allowed definition of wear classes, and the changing dental pattern can be illustrated. The Yapintı fauna is slightly younger than that of Keseköy, but its Sayimys is distinctly smaller. However, in dental morphology, these two assemblages are very similar.

Using the knowledge of the large Sayimys collections from Keseköy and Yapıntı, the Sayimys succession from the Himalayan foreland basin have been reviewed. The succession spans an age ranging from late Oligocene (about $26 \mathrm{Ma})$ till in the Pliocene. Formerly named species are discussed in the light of intra-specific variation. Depending on more material from the type localities to ascertain specific identity, Sayimys baskini is considered a junior synonym of $S$. minor, and $S$. assarrarensis is considered a junior synonym of $S$. intermedius. Since the type localities of Sayimys obliquidens and S. sivalensis are not known, and their type series are small, these names are considered nomina dubia and restricted to their holotypes. The early Miocene Sayimys hintoni n. sp. evolved into the middle and late Miocene $S$. chinjiensis. The middle Miocene Sayimys species from the Indian subcontinent are different from those of more western regions: Turkey, Greece and Saudi Arabia. Sayimys from the Indian subcontinent shows a trend toward larger size: increase in crown-height, simplification of the upper molars by reduction of the para- and metaflexus, to oblique lophids in lower molars and the development of an anterolophulid on the dp4. Most faunas seem to contain one ctenodactylid species, but two early Miocene faunas from the Manchar Formation in the Sind Province of Pakistan record three species: a very small species, Sayimys cf. minor, a medium-sized one, $S$. hintoni and the large $S$. cf. giganteus.

\section{Acknowledgments}

This paper has been adapted from the master thesis of Julian Hartman, who thanks his supervisor Wilma Wessels at the Department of Earth Sciences of Utrecht University. J. Baskin kindly provided measurements and camera lucida drawings; these were used in the review of 
the Pakistan ctenodactylids. The field campaigns in Turkey were organized by the MTA (Turkish Geological Survey) to support their regional mapping projects. Thanks to the great field-geological knowledge of Gerçek Saraç, Engin Ünay and MTA colleagues, many faunas could be collected. Fossils from the localities labelled H.-GSP were collected by participants of the Howard University-Geological Survey of Pakistan project entitled "Cenozoic Mammals and Biostratigraphy of Pakistan". The University of Utrecht is thanked for financial support. M. J. C. Bouten (Utrecht University) assisted in making the SEM photographs, M. Stoete (Utrecht University) prepared the map of Text-fig. 1. The paper benefited from reviews by Laurent Marivaux and Thomas Mörs.

Conflicts of interest: The authors declare that they have no conflicts of interests.

\section{References}

Baskin, J. (1996): Systematic revision of Ctenodactylidae (Mammalia, Rodentia) from the Miocene of Pakistan. Palaeovertebrata, 25: 1-49.

Black, C. C. (1972): Review of fossil rodents from the Neogene Siwaliks beds of India and Pakistan. Palaeontology, 15: 238-266.

Bohlin, B. (1946): The fossil mammals from the Tertiary deposit of Taben-Buluk, Western Kansu Part II: Simplicidenta, Carnivora, Artiodactyla, Perissodactyla, and Primates. - Palaeontologica Sinica, N. S., Ser. C, 8b: $1-259$.

Bruijn, H. de (1999): Superfamily Ctenodactyloidea. In: Rössner, G. H., Heissig, K. (eds), The Miocene Land Mammals of Eürope. Verlag Dr. Friedrich Pfeil, München, pp. 263-266.

Bruijn, H. de, Boon, E., Hussain, S. T. (1989): Evolutionary trends in Sayimys (Ctenodactylidae, Rodentia) from the Lower Manchar Formation (Sind, Pakistan). Proceedings of the Koninklijke Nederlandse Akademie van Wetenschappen, B, 92(3): 191-214.

Bruijn, H. de, Hussain, S. T., Leinders, J. J. M. (1981): Fossil rodents from the Murree formation near Banda Daud Shah, Kohat, Pakistan. - Proceedings of the Koninklijke Nederlandse Akademie van Wetenschappen, B, 84(1): 71-99.

Freudenthal, M., Cuenca Bescos, G. (1984): Size variations of fossil rodent populations. - Scripta Geologica, 76: $1-28$.

Gervais, M. P. (1854): Histoire Naturelle des Mammifères. - L. Curmer, Paris, 420 pp.

Hinton, M. A. C. (1933): Diagnoses of new genera and species of rodents from Indian Tertiary Deposits. Annals and Magazine of Natural History, Series 10, 12: 620-622. https://doi.org/10.1080/00222933308673728

Jacobs, L. L., Flynn, L. J., Downs, W. R. (1989): Neogene rodents of southern Asia. - In: Black, C. C., Dawson, M. R. (eds), Papers on Fossil Rodents in Honour of Albert E. Wood. Science series, Natural History Museum of Los Angeles County, 33: 157-177.
Johnson, N. M., Stix, J., Tauxe, L., Cerveny, P. F., Tahirkheli, R. A. K. (1985): Paleomagnetic Chronology, Fluvial processes and Tectonic implications of the Siwalik Deposits near Chinji village Pakistan. - Journal of Geology, 93: 27-30. https://doi.org/10.1086/628917

Kordikova, E. G., Bruijn, H. de (2001): Early Miocene rodents from the Aktau Mountains (South-Eastern Kazakhstan). - Senckenbergiana lethaea, 81(2): 391405.

https://doi.org/10.1007/BF03042791

Krijgsman, W., Duermeijer, C. E., Langereis, G. C., Bruijn, H. de, Saraç, G., Andriessen, P. A. M. (1996): Magnetic polarity stratigraphy of late Oligocene to Middle Miocene mammal-bearing localities in Central Anatolia (Turkey). - Newsletters on Stratigraphy, 34: 13-29. https://doi.org/10.1127/nos/34/1996/13

Lindsay, E. H., Flynn, L. J. (2016): Late Oligocene and Early Miocene Muroidea of the Zinda Pir Dome. - Historical Biology, 28(1-2): 215-236. https://doi.org/10.1080/08912963.2015.1027888

Lindsay, E. H., Flynn, L. J., Cheema, I. U., Barry, J. C., Downing, K. F., Rajpar, A. R., Raza, S. M. (2005): Will Downs and the Zinda Pir Dome. - Palaeontologia Electronica, 8(1): 19A (19 pp.).

López-Antoñanzas, R., Knoll, F. (2011): A comprehensive phylogeny of the gundis (Ctenodactylinae, Ctenodactylidae, Rodentia). - Journal of Systematic Palaeontology, 9(3): 379-398. https://doi.org/10.1080/14772019.2010.529175

López-Antoñanzas, R., Sen, S. (2003): Systematic revision of Mio-Pliocene Ctenodactylidae (Mammalia, Rodentia) from the Indian subcontinent. - Eclogae Geologicae Helvetiae, 96: 521-529.

López-Antoñanzas, R., Sen, S. (2004): Ctenodactylids from the Lower and Middle Miocene of Saudi Arabia. Palaeontology, 47(6): 1477-1494. https://doi.org/10.1111/j.0031-0239.2004.00424.x

López-Antoñanzas, R, Sen, S., Koufos. G. D. (2005): A ctenodactylid rodent (Mammalia: Rodentia) from the Middle Miocene of Chios Island (Greece). - Geobios, 38: $113-126$. https://doi.org/10.1016/j.geobios.2003.08.006

López-Antoñanzas, R., Sen, S., Saraç, G. (2004): New large ctenodactylid species from the Lower Miocene of Turkey. - Journal of Vertebrate Paleontology, 24(3): 676-688.

https://doi.org/10.1671/0272-4634(2004)024[0676:AN LCSF]2.0.CO;2

Métais, G., Antoine, P.-O., Hassan Baqri, S. R., Crochet, J.Y., De Franceschi, D., Marivaux, L., Welcomme, J.-L. (2009): Lithofacies, depositional environments, regional biostratigraphy and age of the Chitarwata Formation in the Bugti Hills, Balochistan, Pakistan. - Journal of Asian Earth Sciences, 34: 154-167. https://doi.org/10.1016/j.jseaes.2008.04.006

Munthe, J. (1980): Rodents of the Miocene Daud Khel local fauna, Mianwali district, Pakistan. Part 1. Sciuridae, Gliridae, Ctenodactylidae, and Rhizomyidae. - Contributions in Biology and Geology, Milwauke Public Museum, 34: 1-36. 
Qui, Z.-D. (2017): Several rarely recorded rodents from the Neogene of China. - Vertebrata PalAsiatica, 55(2): 92-109.

Sen, S.,Thomas, H. (1979): Découverte de rongeurs dans le Miocène moyen de la Formation Hofuf (Province du Hasa, Arabie saoudite). - Compte Rendu Sommaire des séances de la Société Géologique de France, 1979(1): 34-37.

Sümengen, M., Ünay, E., Saraç, G., Bruijn, H. de, Terlemez, I., Gürbüz, M. (1990): New Neogene rodent assemblages from Anatolia (Turkey). - In: Lindsay, E. H., Fahlbusch, V., Mein, P. (eds), European Neogene Mammal Chronology. Plenum Press, New York, pp. 61-72. https://doi.org/10.1007/978-1-4899-2513-8_5

Theocharopoulos, K. O. (2000): Late Oligocene-Middle Miocene Democricetodon, Spanocricetodon and Karydomys n. gen. from the eastem Mediterranean area. - Gaia, 8: 1-92.

Ünay, E., Atabey, E., Saraç, G. (2001): Small mammals and foraminifera from the Anatolian (Central Taurus) Early Miocene. - Annals of the Carnegie Museum of Natural History, 70(4): 247-256.

Vasishat, R. N. (1985): Antecedents of early man in northwestern India: paleontological and paleoecological evidences. - Inter-India Publications, New Delhi, 230 pp.

Wang, B. (1997): The mid-Tertiary Ctenodactylidae (Rodentia, Mammalia) of Eastern and Central Asia. Bulletin of the American Museum of Natural History, 234: 1-88.

Wang, X., Wang, B., Qiu, Z., Xie, G., Xie, J., Downs, W., Qiu, Z., Deng, T. (2003): Danghe area (western Gansu,
China) biostratigraphy and implications for depositional history and tectonics of northern Tibetan Plateau. - Earth and Planetary Science Letters, 208: 253-269. https://doi.org/10.1016/S0012-821X(03)00047-5

Wessels, W. (2009): Miocene rodent evolution and migration, Muroidea from Pakistan, Turkey and Northern Africa. Geologica Ultraiectina, 307: 1-207.

Wessels, W., Bruijn, H. de (2001): Rhizomyidae from the lower Manchar Formation (Miocene, Pakistan). - Annals of the Carnegie Museum of Natural History 70(2): 143168.

Wessels, W., Bruijn, H. de, Hussain, S. T., Leinders, J. J. M. (1982): Fossil rodents from the Chinji Formation, Banda Daud Shah, Kohat, Pakistan. - Proceedings of the Koninklijke Nederlandse Akademie van Wetenschappen, B, 85(3): 337-364.

Wessels, W., Fejfar, O., Peláez-Campomanez, P., Meulen, A. van der, Bruijn, H. de (2003): Miocene small mammals from Jebel Zelten, Libya. - Coloquios de Paleontologica, Vol. Ext. 1: 699-715.

Wessels, W., Theocharopoulos, K. O., Bruijn, H. de, Ünay, E. (2001): Myocricetodontinae and Megacricetodontini (Rodentia) from the lower Miocene of NW Anatolia. - In: Horáček, I., Míkovsky, J. (eds), Papers in paleomammalogy honoring Prof. Dr. Oldřich Fejfar. Lynx, N.S., 32: 371-388.

Wood, A. E. (1937): Fossil rodents from the Siwalik beds of India. - American Joumal of Science, 34: 64-76. https://doi.org/10.2475/ajs.s5-34.199.64 